\title{
Diversification as Part of a CSA Strategy: The Cases of Zambia and Malawi
}

\author{
Aslihan Arslan, Solomon Asfaw, Romina Cavatassi, Leslie Lipper, \\ Nancy McCarthy, Misael Kokwe, and George Phiri
}

\begin{abstract}
Climate variability, associated with farm-income variability, is recognized as one of the main drivers of livelihood diversification strategies in developing countries. In this chapter, we present a synthesis of two comprehensive studies from Zambia and Malawi on the drivers of diversification and its impacts on selected welfare outcomes with a specific attention to climatic variables and institutions. We use geo-referenced farm-household-level data merged with data on historical rainfall and temperature as well as with administrative data on relevant institutions. The two case studies demonstrate that diversification is clearly an adaptation response, as long term trends in climatic shocks have a significant effect on livelihood diversification, albeit with different implications. Whereas the long term variation in growing period rainfall is associated with increased crop, labour and income diversification in Malawi, it is only associated with increased livestock diversification in Zambia. With regard to institutions, we find that access to extension agents positively and significantly correlates with crop diversification in both countries, underlining the role of extension in promoting more resilient farming systems in rural Zambia and Malawi. Fertilizer subsidies are among the most important agricultural policies in both countries, where they significantly affect incentives for income diversification - though in opposing ways - providing important policy implications. The two case studies document distinct ways in which incentives for livelihood diversification (measured along different dimensions) are shaped by increased
\end{abstract}

\author{
A. Arslan $(\bowtie) \cdot R$. Cavatassi \\ International Fund for Agricultural Development (IFAD), Rome, Italy \\ e-mail: a.arslan@ifad.org \\ S. Asfaw \\ FAO of the UN, Rome, Italy \\ L. Lipper \\ ISPC-CGIAR, Rome, Italy \\ N. McCarthy \\ Lead Analytics Inc., Washington, DC, USA \\ M. Kokwe \\ FAO of the UN, Lusaka, Zambia \\ G. Phiri \\ FAO of the UN, Lilongwe, Malawi
}

(C) FAO 2018

L. Lipper et al. (eds.), Climate Smart Agriculture, Natural Resource

Management and Policy 52, DOI 10.1007/978-3-319-61194-5_22 
variability in rainfall and rural institutions. The results also demonstrate that diversification can be an effective adaptation response and the risk-return trade-offs are not as pronounced as might be expected.

\section{Introduction}

Livelihood diversification strategies are implemented by households in rural environments as a response to threats and opportunities to manage risk and increase or stabilize income and consumption. Most households in rural areas of developing countries rely on rain-fed agriculture for their livelihoods and, as such, are highly dependent on climatic conditions. Recent evidence and projections indicate that global climate change is likely to increase the incidence of natural hazards, including the variability of rainfall, temperature and occurrences of climatic shocks (IPCC 2014). As a consequence, all aspects of food security may be potentially threatened by the effects of changes in climate, including food availability, access, utilization, and stability (e.g., Challinor et al. 2010; IPCC 2014). In this context, diversification strategies play a crucial role in ensuring food security under climate change, as they have the potential to address two of the CSA pillars by contributing to food security and adaptation to climate change.

Economic theory, however, suggests that there may be potential tradeoffs between food security and adaptation (i.e. between risk and return), specifically related to diversification behaviour. The potential for tradeoffs and synergies depends on the type of diversification in question and the factors that drive it including climatic and institutional factors. We present a synthesis of two comprehensive studies on the drivers of diversification as well as selected welfare outcomes with a specific attention to climatic variables and institutions in this chapter.

We first provide an overview of the literatures on livelihood diversification, vulnerability and climate change to situate diversification in the CSA agenda. We then present empirical evidence from Zambia and Malawi to better understand the linkages between climate shocks, diversification and welfare outcomes with a goal to highlight potential policy entry points to incentivize the types of diversification that help households to improve food security and resilience to climate shocks. We close with a synthesis of results and policy implications.

\section{Concepts in the Literature}

\subsection{Livelihood Diversification and Vulnerability}

Diversification strategies in the presence of imperfect information and risk are acknowledged among the most fundamental theoretical insights in economics. The economic theory of expected utility maximization leads to diversification under risk 
aversion even when credit and insurance markets function (Alderman and Paxson 1992). Whereas this result applies in many different sectors (e.g. finance, industrial production), the particularities of agricultural production (seasonality in demands for inputs, heterogeneity in land quality or spatial constraints on allocation of resources, dependence on weather patterns) set it apart from other sectors. Specifically, diversification in agricultural production can arise even without invoking risk or under conditions where specialization would be expected (Just and Pope 2001; Alderman and Sahn 1989; Pope and Prescott 1980). The conditions that lead to diversification are further amplified in rural economies, where credit and insurance markets are missing/imperfect, as diversification takes on a role to fill in the risk-management needs left unmet by these markets (Binswanger 1983; Reardon 1997).

Agricultural households in rural economies can adopt diversification leading to better risk-management and smoother income streams ex-ante (Smit and Wandel 2006) but also as an involuntary ex-post short-term adjustment to smooth consumption in the wake of shocks or crisis, when ex-ante risk mitigation strategies are insufficient (Davies and Hossain 1997; Murdoch 1995). The ability of a livelihood system to respond to shocks through coping strategies is thus a key determinant of livelihood resilience and vulnerability, together with ex-ante risk mitigation (Adger 1999; Bryceson 1996, 1999; Delgado and Siamwalla 1999; Toulmin et al. 2000; Barrett et al. 2001a; Adger et al. 2005; Folke 2006).

These two types of diversification can be on-farm (e.g. planting a crop or variety mix, or combining crop and livestock operations) or off-farm (e.g. differentiating income sources through wage employment on others' farms or in other sectors, starting own business or migration of a household member). The classifications along on-farm vs. off-farm sectors are still used in the literature despite Barret's (2001) call for a unified diversification classification along sectoral and spatial lines. Regardless of the terminology, what matters is that the returns to the chosen bundle of assets, activities and incomes should ideally be perfectly negatively correlated or just not perfectly correlated with each other to be able to act as a smoothing strategy.

The extensive literature on the drivers of diversification tends to classify the drivers into push and pull factors (Reardon 1997; Barret 2001). Push factors include imperfect credit and insurance markets, stagnation in the agricultural sector, high transaction costs, as well as adverse shocks, hence the diversification that is driven by them need not necessarily improve average incomes (Barrett et al. 2001a; Reardon et al. 2007; Lay et al. 2009). Pull factors, on the other hand, include a booming non-farm sector or new/improved technologies in the farm sector, which lead to diversification that is more likely correlated with improved average outcomes, as well as reduced variability of those outcomes (Reardon et al. 2007; Bandyopadhyay and Skoufias 2013).

When pull factors dominate, livelihood diversification can be a phase in the transition from subsistence to commercial agriculture or non-farm activities, and implicitly a transition out of poverty (Pingali and Rosengrant 1995). Pull factors, however, tend to dominate for wealthier and more educated households, or in areas where access to markets, infrastructure and urban centers are better (Lanjouw et al. 2001; 
Fafchamps and Shilpi 2003, 2005; Deichmann et al. 2008; Babatunde and Qaim 2009; Davis et al. 2010; Losch et al. 2011). The majority of empirical evidence on rural households in Sub-Saharan Africa suggest that pull factors dominate for income and labour diversification, so that wealth, education and access to densely populated areas are correlated with higher labour and income diversification, whereas poverty is correlated with higher crop diversification and lower income and labour diversification (Barrett et al. 2001a; Lanjouw et al. 2001; Babatunde and Qaim 2009; Dimova and Sen 2010; Asmah 2011). Though more difficult to establish due to endogeneity issues, the empirical evidence also suggests that more diversified households have higher incomes and greater consumption per capita (Ersado 2003; Babatunde and Qaim 2009; Asmah 2011).

A better understanding of the factors driving diversification by rural households would therefore provide insights into the role of diversification in poverty reduction, food security and development. It would also help design policies that explicitly address diversification as possible determinants of future levels of welfare and foster institutions to support welfare-improving diversification (Barrett et al. 2001b).

The relationship between diversification and vulnerability at the household level seems conceptually clear at first: as the motivation to spread risk over multiple activities is at the heart of diversification, vulnerability should decline as diversification increases. However, while this may be true for deliberate ex-ante diversification that leads to less variable incomes, the opposite may be true for forced or ex-post diversification (Barrett et al. 2001a; Bandyopadhyay and Skoufias 2013). Here we have just defined vulnerability as "variability in incomes;" however, there are multitudes of vulnerability definitions and measures that complicate the issue even further (Moret 2014). Disentangling the cause and effect linkages between diversification and vulnerability is very difficult given the dynamic relationships between them: while the more vulnerable may be more likely to diversify today to prevent negative effects of shocks in the future, the fact that they diversify may allow them to build-up assets/human capital that leads them to be less vulnerable in the future. This difficulty is amplified in the absence of longitudinal data covering an identifiable shock (idiosyncratic or systemic) to track the patterns of household diversification and welfare outcomes over time. Empirical analyses of these complex relationships based on cross-sectional data, therefore, need to be very careful in attributing causality, as in the case studies presented in this chapter.

\subsection{How Does Climate Change Enter the Picture?}

Agriculture is exposed to various forms of risk ranging from weather variability to pests and diseases to price volatility in output, input and factor markets. For agricultural households that rely on rainfall and face imperfect market conditions that characterize rural economies, these risks take greater prominence as they lack the means to manage risk effectively (e.g. by investing in irrigation, buying insurance or using credit to smooth income and consumption). Climate change multiplies these risks by increasing the probability and severity of unfavorable weather conditions that 
affect the livelihoods of households in various ways. Direct effects include the decreases in agricultural productivity (crops, livestock, fisheries and forestry), and indirect effects include a decrease in demand for labour, increased local prices, decreased access to markets due to negative impacts on infrastructure, among others. Climate change not only decreases incomes today, but also makes them less predictable by changing the probability distributions in ways that are difficult for households to incorporate into their decision-making (Lipper and Thornton 2014).

Climate change is expected to have generally negative effects on developingcountry agriculture, hence on food security. Climate shocks such as drought, flooding, and extreme temperatures are expected to increase in frequency and intensity, and these impacts are projected to increase over time (Nelson and van der Mensbrugghe 2013; IPCC 2012). In the absence of measures to reduce the vulnerability to, and impacts of, such extreme events, they can be expected to generate significant negative impacts on food security (FAO 2010; Foresight 2011).

The impacts of climate change can be generally classified as push factors for diversification as risk-averse farmers implement ex-ante risk management strategies (by diversifying crops, other agricultural activities or incomes) and trade a part of their expected earnings with a lower variability in income (Alderman and Paxson 1992; Reardon et al. 1998, 2000, 2007; Barrett et al. 2001a). While climate variability associated with farm-income variability is already recognized as one of the main drivers of diversification in developing countries, the above-mentioned impacts of climate change give further incentives for diversification into activities that are less susceptible to disruption from climatic shocks (Newsham and Thomas 2009).

Empirical evidence on the role of diversification as an adaptation strategy is growing. Crop diversification is shown to help farmers deal with droughts in Nigeria (Mortimore and Adams 2001) and other shocks leading to crop failure in Ethiopia (Di Falco and Chavas 2009; Cavatassi et al. 2011), while income and livelihood diversification are shown to help households deal with weather shocks in Zimbabwe and Nicaragua (Ersado 2003; Macours et al. 2012). This chapter contributes to this literature with two case studies based on nationally representative data as well as high resolution historical data on climatic shocks.

\subsection{Diversification as CSA}

The above discussion on diversification, vulnerability and climate change naturally leads to the realm of CSA, as these concepts are directly concerned with the food security and adaptation pillars of CSA. Adaptation is defined by the IPCC fourth assessment report as "the adjustment in natural or human systems in response to actual or expected climatic stimuli or their effects" (IPCC 2007). This implies a permanent change in the livelihood system leading to better risk-management or coping capacity in the long-run (Smit and Wandel 2006). Diversification at household, village, landscape and national levels is one of the ways of adapting to the changes in climatic patterns and thus of building resilience to climate change, hence it is frequently mentioned in the international CSA policy discourse (FAO 2010; 
FAO 2013; Campbell et al. 2014). At the national level, thirteen countries that have submitted National Adaptation Programmes of Action (out of 48) to the United Nations Framework Convention on Climate Change (UNFCCC) have projects focused explicitly on diversification (of crops, livestock, fisheries, livelihoods) as an adaptation strategy. ${ }^{1}$ Eleven out of these thirteen are in Sub-Saharan Africa (SSA), where about $30-50 \%$ of rural households rely on non-farm income for their total income (Ellis 1998; Reardon 1997; Reardon et al. 1998). ${ }^{2}$ Many countries in SSA, including Zambia and Malawi, have also made diversification part of their national agricultural investment strategies/plans and aim to build the necessary enabling environment to support the types of diversification that build resilience.

The ideal enabling environment for diversification choices would consist of institutions and markets that turn push factors into pull factors by facilitating higher income levels with lower levels of variability under the expected climatic shocks. For example, while households may diversify their crops by incorporating legumes into maize plots to buffer maize from rainfall and temperature shocks (especially when inorganic fertilizer use is negligible), this strategy may result in lower incomes if there is no established market for legumes. Improving access to markets and value chains for legumes would be part of a CSA strategy in this context as it would both improve incomes and make them more resilient to weather shocks. Such a strategy has also the potential to contribute to the mitigation pillar, as legume intercropping (by fixing nitrogen in the soil) would decrease the need for inorganic fertilizers, the production and inefficient use of which contribute to the emissions produced by agriculture. These types of mitigation potentials, however, should be considered a co-benefit only in rural environments based on small-scale agriculture, where food security and adaptation are the development priorities.

\section{Empirical Evidence from Malawi and Zambia}

In what follows, we synthesize the results of two empirical studies that investigate the factors driving diversification and the relationship with vulnerability in Malawi and Zambia. ${ }^{3}$ These case studies form part of the evidence base for a project on CSA that was funded by the European Commission (EC) and implemented by the Economic and Policy Innovations for CSA (EPIC) programme in FAO during 2012-2015.

\footnotetext{
${ }^{1}$ UNFCCC established a work programme for least developed countries (LDC) in 2001 that include national adaptation programmes of action (NAPA), to support LDCs to address the challenge of climate change given their particular vulnerability. NAPAs provide a process for LDCs to identify priority activities that respond to their urgent and immediate needs to adapt to climate change - those for which further delay would increase vulnerability and/or costs at a later stage. For further information: http://unfccc.int/adaptation/workstreams/national_adaptation_programmes_of_action/items/7572.php.

${ }^{2}$ http://unfccc.int/adaptation/workstreams/national_adaptation_programmes_of_action/ items/4583.php.
}

${ }^{3}$ The Malawi analysis synthesized here is based on Asfaw et al. (2015). 
This project was the first of its kind focused on evidence based development intended for policy support to CSA to improve the efficiency of policy making and targeting for sustainable improvements in food security under climate change. By combining two case studies in a comparative analysis and linking them closer with CSA, this chapter provides a broader perspective on the role of diversification as part of a CSA approach to agricultural development policy.

Both Malawi and Zambia already face the negative impacts of climate change manifested in increasing frequency of droughts and floods, as well as increased temperatures in certain parts of both countries (Thurlow et al. 2012; Kanyanga et al. 2013). This chapter provides an insight into the role of climatic shocks in driving diversification, vulnerability outcomes and the types of institutions that may help support diversification and adaptation in SSA, inasmuch as the climatic, socioeconomic and political conditions in these two countries are characteristic of SSA.

\subsection{Country Background}

Zambia ranks 15th in the list of countries that are most vulnerable to climate change (Wheeler 2011). The agricultural sector accounts for approximately $20 \%$ of the GDP, and around $80 \%$ of the rural population lives below the poverty line (World Bank 2013; Chapoto et al. 2011). Furthermore, the fact that $64 \%$ of the total population lives in rural areas that primarily depend on rain-fed subsistence agriculture provides a glimpse into the rural vulnerability to various shocks, be it weather shocks or other shocks typical of the agricultural sector (input/output price shocks).

Temperatures in Southern Africa are projected to increase by $0.6-1.4^{\circ} \mathrm{C}$ by 2030 and by $1.5-3.5^{\circ} \mathrm{C}$ during 2040-2069 (Lobell et al. 2008; Kihara et al. 2015). Rainfall predictions are more ambiguous, with models suggesting either reduced or increased precipitation (Lobell et al. 2008). Regional models, however, agree more on the prediction of decreased rainfall for Southern Africa (Kihara et al. 2015).

Zambia has four distinct agro-ecological regions (AER) and the predicted impacts of climate change differ across AERs (Fig. 1). The western and southern parts of the country (AER I) are exposed to low, unpredictable and poorly distributed rainfall in general, whereas the central part of the country (AER IIa \& b) has the highest agricultural potential, with well distributed rainfall (Jain 2007). Zambia-specific climate models predict that rainfall will decrease and temperatures will increase in AER I and II, while rainfall will increase in the northern parts of the country (AER III) (Kanyanga et al. 2013). Combined with projections of prolonged drought and dry spells, maize production is expected to be severely affected in these regions that cover the majority of Zambia's maize growing area. Increased rainfall on the already leached soils of AER III that are also acidic is expected to have a negative impact on crop production. It is also predicted that climate variability will increase, which has reduced the country's economic growth by four percentage points over the last 10 years pulling an additional $2 \%$ of the population into poverty (Thurlow et al. 2012). Empirical analyses show that agricultural technologies 


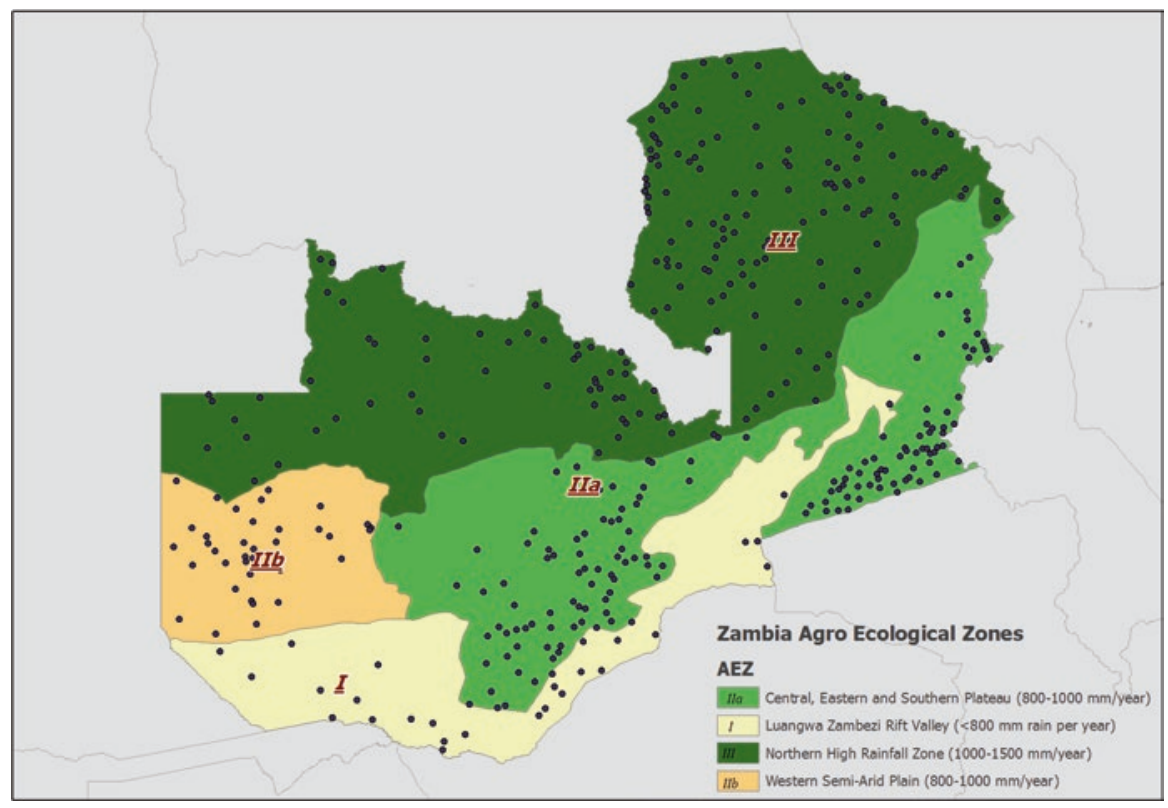

Fig. 1 Zambia's AER overlaid with the household data points

promoted in rural Zambia, including sustainable agricultural practices as well as the use of modern inputs, are not suited to deal with various shocks expected to get worse under climate change and a more tailored approach is needed to support agricultural growth and food security (Arslan et al. 2015).

The recent Zambia Vulnerability and Needs Assessment Report (VNAR) prepared as a response to prolonged droughts in the 2015 season shows that agriculture is the main income source for $60 \%$ of the population and that droughts increased food insecurity in 31 of 48 districts assessed, as approximately 800,000 people were in need of food relief (VAC 2015). It was also observed that costly risk-coping mechanisms were commonly adopted in response, leading to the recommendation that "livelihood diversification programmes be scaled up to reduce dependency on agriculture based activities in view of climate shocks" (VAC 2015). By providing detailed insight into the drivers of diversification under climate change and how institutions may help foster diversification to decrease vulnerability, this chapter provides timely evidence to support policy in Zambia.

Malawi is ranked the world's 12th most vulnerable country to the adverse effects of climate change (Wheeler 2011). As in the case of Zambia, projected impacts of climate change combined with the prominence of subsistence farming makes livelihoods vulnerable to climate-related stressors in a number of ways. These include increased exposure to extreme climate events, such as droughts, dry spells, floods, as well as erratic and unreliable rainfall (Chinsinga 2012). Predicted climate change impacts in Malawi are likely to significantly affect smallholders, who depend on rainfall (Denning et al. 2009). 
A synthesis of climate data by the World Bank indicates that over the period of 1960 to 2006, mean annual temperature in Malawi increased by $0.9{ }^{\circ} \mathrm{C}$ (World Bank 2012). This increase in temperature is concentrated in the rainy summer season (December-February), and is expected to increase further. However, long-term rainfall trends are difficult to characterize due to the highly variable inter-annual rainfall pattern in Malawi. It should be also noted that assessments of climatechange impacts on Malawian agriculture are highly variable across agro-ecological zones (Boko et al. 2007; Seo et al. 2009). Still, given that agricultural production remains the main source of income for most rural communities, the increased risk of crop failure due to projected increases in the frequency of extreme climate events poses a major threat to food security. Adaptation of the agricultural sector to the adverse effects of climate change is thus an important priority for food security (Bradshaw et al. 2004; Wang et al. 2009).

Malawi is one of the least diversified economies in the world, where $84 \%$ of the working population is employed in agriculture (the Welfare Monitoring Survey ILO 2010). In terms of income sources, about $50 \%$ of the households derive their income mainly from agriculture and another $25 \%$ from a second source (FinScope survey as reported in ILO 2010). Privately owned businesses are common, providing income for over $20 \%$ of households, and around $15 \%$ have salary or wage income, whereas other sources of income altogether are less than 10\% (ILO 2010). Although there is a discrepancy between different surveys, contract labour is reported to be the main source of income for $1-15 \%$ of individuals.

The government of Malawi has been trying to address the challenges associated with climate change in various ways. The National Adaptation Programme of Action (NAPA), formulated in 2006, is one of the key climate-change policy documents (GoM 2006; Chinsinga 2012). The Ministry of Agriculture and Food Security operationalizes NAPA priorities through the Agriculture Sector Wide Approach (ASWAp), which identifies several strategies, including diversification, to increase the resilience of rural areas to climate change (GoM 2008; Chinsinga 2012). In-depth studies like the one synthesized here are critical for the efficient design and implementation of such strategies.

\subsection{Data Sources}

The case studies presented in this chapter are based on three main data sources: nationally representative household surveys, historical rainfall and temperature data at high resolution from publicly available data sources, and administrative data on relevant institutions that were collected as part of the project.

For the case of Zambia, the household data come from the 2012 Rural Agricultural Livelihoods Survey (RALS) collected by the Central Statistics Office (CSO) in collaboration with Michigan State University (MSU) and the Indaba Agricultural Policy Research Institute (IAPRI). The data set is nationally representative and includes detailed information on agriculture (crop and livestock) practices, 
other sources of off-farm rural activities along with household demographic characteristics as well as social capital indicators. The sample consists of more than 8,000 farmers, which are representative at the province level (and at the district level in the Eastern province).

For Malawi, the household data are from the World Bank's Third Malawi Integrated Household Survey (IHS3), which was conducted from March 2010 to March 2011. The IHS3 survey is nationally representative and covers information on various aspects of community and household composition, characteristics and socio-economic status, as well as agriculture-specific production characteristics. The final sample includes a total of 12,271 households that are representative at the district-level IHS (2012). ${ }^{4}$

The RALS and IHS3 data were merged with a set of rainfall and temperature variables that characterise the historical trends as well as current period shocks in these variables, which are closely linked with agricultural production. Rainfall variables are based on data from the Africa Rainfall Climatology version 2 (ARC2) of the National Oceanic and Atmospheric Administration's Climate Prediction Center (NOAA-CPC) for the period of 1983-2012. ARC2 data are based on the latest estimation techniques on a daily basis and have a spatial resolution of 0.1 degrees $(\sim 10 \mathrm{~km}) .{ }^{5}$ We also use data from the Harmonized World Soil Database (HWSD) with a resolution of 30 arc-seconds to control for the effects of soil quality on incentives for diversification. ${ }^{6}$

Lastly, administrative data on rural institutions including extension and other sources of agricultural information, credit sources, local community groups, were collected at district level in both countries to better understand the rural institutions that play a role in household livelihood strategies. These data on the availability of rural institutions provide an opportunity to deal with the endogeneity issue in selfreported access variables from household surveys.

\subsection{Empirical Model}

Diversification outcomes at the household level are the result of household optimisation decisions subject to multiple constraints (e.g. imperfect labour, land, credit or insurance markets, and transaction costs) as in standard agricultural household models (Singh et al. 1986; de Janvry et al. 1991). Given the imperfect market conditions pervasive in rural areas of developing countries and the multiple push and pull factors explained above that drive households to diversify their income

\footnotetext{
${ }^{4}$ Malawi IHS3 Basic Information Document. Last accessed 21 October 2014 at: http://siteresources.worldbank.org /INTLSMS/Resources/3358986-1233781970982/5800988-1271185595 871/IHS3.BID.FINAL.pdf.

${ }^{5}$ See http://www.cpc.ncep.noaa.gov/products/fews/AFR_CLIM/AMS_ARC2a.pdf for more information on ARC2.

${ }^{6}$ See http://webarchive.iiasa.ac.at/Research/LUC/External-World-soil-database/HTML/ for more information.
} 
generating activities (both within the farm and off-farm sectors), the observed diversity outcomes can be modelled as functions of endowments and indicators of push and pull factors to test various hypotheses on the drivers of diversification (van Dusen and Taylor 2005).

We use the following estimating equation to understand the drivers of diversification including climatic variables as well as relevant institutions in each country:

$$
D_{i j}=\beta_{0}+\beta_{1} C_{k}+\beta_{2} X_{i}+\beta_{3} G_{k}+\beta_{4} I_{d}+\varepsilon_{i}
$$

where $D_{i j}$ is the diversification index for household $i$ for the dimension $j$ analysed (e.g., crop, livestock, labour or income), $C_{k}$ are climatic variables at ward or enumeration area (EA) level (respectively for Zambia and Malawi), $X_{i}$ are household level variables including socio-demographic characteristics and wealth and social capital indicators, $G_{k}$ are variables that capture community characteristics at the ward or EA level, and $I_{d}$ are institutional variables at the district level. In the remainder of this chapter, we first present a descriptive analysis for both countries and then the results of the diversification models described in Eq. (1), before we close with synthesis and policy recommendations.

\subsection{Descriptive Analysis}

\subsubsection{Zambia}

Diversification can be measured along many dimensions using a variety of different indices. Given the high share of agriculture in total incomes of households in our sample ( $72 \%$ on average), the importance placed on diversification into livestock activities as well as diversification of livelihoods in general in the national policy (e.g. NAIP, VNAR, INDC), we measure diversification along three dimension: crops, livestock and income. ${ }^{7}$ Given the AER-specific rainfall regimes and predicted climate change impacts, as well as distinct soil structures, one might expect distinct incentives for crop, livestock and income diversification in each AER. We first present descriptive statistics on diversification by AER to provide an understanding of the livelihood structures across the country.

Table 1 summarizes the shares of total agricultural income (from crops and livestock) and livestock income in total income (only for those that have livestock income) by AER to demonstrate the importance of the dimensions along which we analyse diversification in Zambia. Almost three quarters of total income comes from agriculture in our sample, with a variation between 60 percent in AER I and 76 percent in AER IIa. Livestock income is most important in AER I contributing a

\footnotetext{
${ }^{7}$ The income categories used are based on the IAPRI methodology of defining income sources and consist of income from crops, livestock, businesses, remittances, agricultural wages and non-agricultural wages.
} 
quarter of agricultural income (and 14\% of total income) as expected given the fact that it covers the provinces where majority of traditional livestock herders live, and least important in AER III with a share of 9\% (5\%) of agricultural (total) income.

Diversification is measured by different types of indices in the literature, ranging from simple count indices (Jones et al. 2014) or income shares from different sources (Lay et al. 2008; Davis et al. 2010), to more complex indices usually borrowed from biology literature (Smale 2006), which account for evenness, abundance or both. We use the Gini-Simpson index defined as $\left(1-\sum_{\mathrm{t}}^{i} \mathrm{w}_{i}^{2}\right)$, where $\mathrm{w}_{i}$ is the number of distinct diversity units in the corresponding index $i .^{8}$ These are: (a) the area share allocated to different crop species for crop diversification, (b) the shares of different livestock species' contributions to the total livestock holdings measured by Tropical Livestock Units (TLU) for livestock diversification, ${ }^{9}$ and (c) the monetary shares of income sources disaggregated into six categories for income diversification (see footnote 7).

The main criteria used to distinguish the AER in Zambia is the average rainfall, which combined with different trends in both rainfall and temperature leads to distinct projections in climate models. Given that climatic shocks are one of the important push factors into livelihood diversification, we first discuss the status of diversification by AER. Table 2 shows both the count and Gini-Simpson indices by AER. AER III is the most diversified in terms of crops with more than

Table 1 Share of agricultural and livestock incomes by AER

\begin{tabular}{l|l|l|l}
\hline AER & Ag. Inc./ Total Inc. & Lvsk. Inc./ Ag. Inc. & Lvsk. Inc./ Total Inc. \\
\hline I & 0.60 & 0.25 & 0.14 \\
\hline IIa & 0.76 & 0.14 & 0.09 \\
\hline IIb & 0.72 & 0.15 & 0.09 \\
\hline III & 0.72 & 0.09 & 0.05 \\
\hline Total & 0.73 & 0.13 & 0.08 \\
\hline
\end{tabular}

Table 2 Average count and Gini-Simpson indices of diversification by AER

\begin{tabular}{l|l|l|l|l|l|l}
\hline & \multicolumn{3}{|l|}{ Count indices } & \multicolumn{3}{l}{ Gini-Simpson indices } \\
\hline AER & Crops & Livestock & Income sources & Crops & Livestock & Income sources \\
\hline I & 1.94 & 1.71 & 2.61 & 0.28 & 0.27 & 0.34 \\
\hline IIa & 2.44 & 1.75 & 2.66 & 0.40 & 0.27 & 0.31 \\
\hline IIb & 2.15 & 0.79 & 2.20 & 0.39 & 0.12 & 0.28 \\
\hline III & 2.74 & 1.10 & 2.64 & 0.43 & 0.14 & 0.28 \\
\hline Total & 2.51 & 1.37 & 2.61 & 0.40 & 0.20 & 0.30 \\
\hline
\end{tabular}

\footnotetext{
${ }^{8}$ Count, Simpson and Berger-Parker indices were also constructed and used in analyses for robustness checks. We present results based on the Gini-Simpson index which performed the best.

${ }^{9} \mathrm{TLU}$ is created using the following weights for livestock species: horse (0.8), cattle (0.7), donkey (0.5), pig (0.2), sheep and goat (0.1), chicken, duck and fowl (0.01).
} 
2.7 crop species per household, followed by AER IIa and IIb (2.4 and 2.2 species, respectively). AER IIa is the most diversified region in terms of livestock as expected with an average of 1.75 types of livestock per household, followed by AER I and AER III. Households in all AERs have on average at least two income sources. AER IIa has the highest count index of income diversification, followed by AER III. The income diversification is the only dimension that switches the rankings going from count index to Gini-Simpson index, as AER I has the highest Gini-Simpson index for income diversification, indicating that the income shares are more equally distributed in this region contributing more to diversity (measured by proportional abundance) even though it is the third most diverse by the count index.

The observed diversification patterns are the results of both push and pull factors, and the AER classification provides only a broad insight into the climatic push factors into diversification. For example, given the projections of higher temperatures and even lower rainfall in AER II, if the push factors dominate we might expect increased income diversification with lower welfare in this region. AER IIa, however, also includes the urban centers of Lusaka and Eastern provinces, which provide opportunities for pull factors that might be associated with higher diversification at higher welfare levels. Similarly, AER III is projected to have increased rainfall on soils that are already highly leached, but it also includes Copperbelt province with significant mining activity providing potential pull factors. Understanding which factors dominate in driving diversification and what types of welfare outcomes might be expected requires analyses at higher resolution that control for all potential factors as we do below.

We first look at district level climatic variables and diversification outcomes before moving to household level analysis. Figure 2 shows the distribution of long term average of seasonal rainfall and its coefficient of variation $(\mathrm{CoV})$, and Fig. 3 shows the diversification indices by district. Whereas the long run average rainfall in our data conforms to the classification of AER, there is more heterogeneity across districts within AERs in terms of $\mathrm{CoV}$ of rainfall indicating climate risk management strategies need to be based on site-specific analyses. It is interesting to note that households seem to diversify their crops more in areas with higher long term average seasonal rainfall, and similarly livestock diversification seems higher in areas where the long term variation in rainfall is higher. Income diversification on the other hand shows no clear pattern correlated with the weather variables plotted in Fig. 3. The heterogeneity within AERs in climatic variables (especially for the variation in rainfall over time) and diversification, provides further evidence that agricultural development planning at the AER level may not be able to capture all factors at play in shaping livelihood decisions. The unconditional averages plotted in these figures provide suggestive evidence only, as it remains to be seen whether and how weather shock variables drive diversification outcomes controlling for other variables that affect livelihood decisions and risk attitudes. 

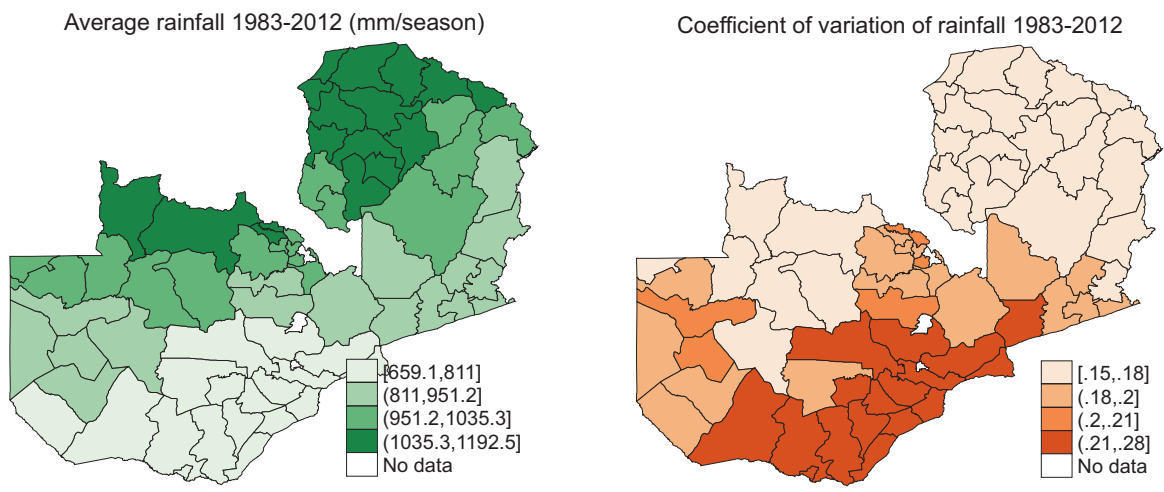

Fig. 2 Average growing season rainfall and its coefficient of variation over 1983-2012

Table 3 presents the descriptive statistics of all control variables used in the analyses on the determinants of diversification. ${ }^{10}$ Our climate variables include the long term (1983-2012) coefficient of variation of rainfall during the cropping season and the current period rainfall anomaly constructed as the deviation of the rainfall in the season covered by the survey from the long term average. While the coefficient of variation captures the effect of long term variation in rainfall on ex-ante incentives, the current period anomaly captures the immediate effect of shocks on diversification (e.g. household being pushed into petty jobs to substitute for agricultural income lost due to a shock). Around $24 \%$ of household heads are female, and this variable may be expected to have a negative effect on diversification a priori, as female-headed households would find it more difficult to access resources that enable them to take advantage of pull opportunities for diversification (Ellis 1998; Davies and Hossain 1997). However, based on evidence in the literature to suggest that women are more risk averse (Hartog et al. 2002; Borghans et al. 2009), which should "push" them into diversification, the combined effect of gender on diversification is ambiguous and may differ by types of diversification analysed here. Number of household members is a proxy for labour availability and the average household in our sample has 5.4 members. We use operated land size in hectares (2.8) and a household wealth index constructed by principal component analysis based on data on dwelling characteristics as well as the ownership of a large set of assets as wealth indicators.

Social capital and market access can act as pull factors for diversification as households share information and knowledge in groups or in market places that act as information hubs (Cavatassi et al. 2012). We use the share of households in an SEA that participate in farmer cooperatives, women's groups or savings and loan

\footnotetext{
${ }^{10}$ The control variables in both countries are carefully constructed to control for potential endogeneity issues as much as possible in cross-sectional studies. Institutional variables are taken from the district/enumeration area level dataset rather than from household's self-reported values and wealth indices are constructed using the ownership of pre-determined durables. Given the crosssectional nature of the analyses, this is the best that can be done to control potential endogeneity.
} 

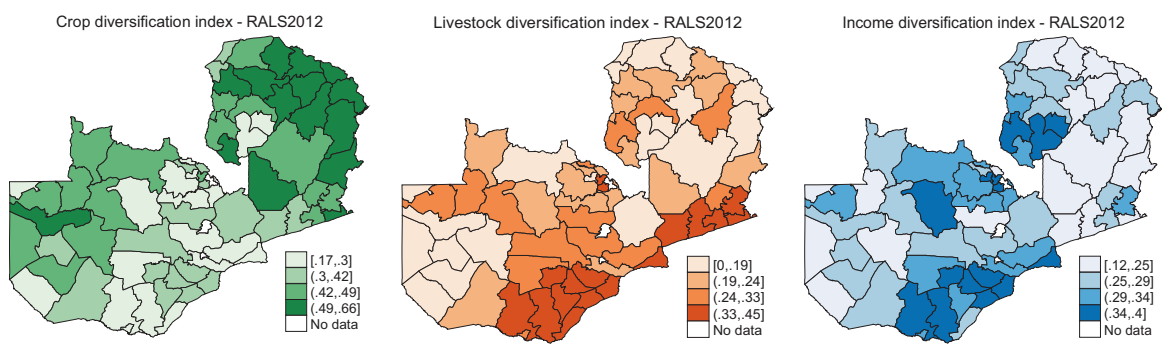

Fig. 3 Diversification indices in RALS 2012 data by district

Table 3 Descriptive statistics of control variables (Nr. of observations $=8,219$ )

\begin{tabular}{|c|c|c|c|c|}
\hline Variable & Mean & Std.Dev & Min & $\operatorname{Max}$ \\
\hline \multicolumn{5}{|l|}{ Climate variables } \\
\hline CoV of Oct-Apr rainfall 1983-2012 & 19.52 & 3.01 & 13.52 & 29.61 \\
\hline Rainfall anomaly during $2010-11$ season & 0.08 & 0.09 & 0.00 & 0.38 \\
\hline \multicolumn{5}{|l|}{ Household socio-demographic } \\
\hline Head is female & 0.24 & 0.43 & 0.00 & 1.00 \\
\hline Age of household head & 44.66 & 15.57 & 17.00 & 111.00 \\
\hline Number of household members & 5.40 & 2.54 & 1.00 & 29.00 \\
\hline Avg adult yrs. of education & 5.59 & 2.84 & 0.00 & 18.00 \\
\hline \multicolumn{5}{|l|}{ Household wealth } \\
\hline Land size in hectares & 2.77 & 3.82 & 0.00 & 71.56 \\
\hline Wealth index (PCA excluding livestock) & -0.54 & 1.86 & -2.46 & 26.42 \\
\hline \multicolumn{5}{|l|}{ Social capital \& market access } \\
\hline Group membership share in SEA & 0.49 & 0.24 & 0.00 & 1.00 \\
\hline Head/spouse is kin of chief & 0.11 & 0.32 & 0.00 & 1.00 \\
\hline Head/spouse is kin of headman & 0.49 & 0.50 & 0.00 & 1.00 \\
\hline Distance to road $(\mathrm{km})$ & 32.91 & 38.01 & 0.00 & 247.00 \\
\hline Distance to established market place $(\mathrm{km})$ & 27.46 & 23.35 & 0.00 & 153.30 \\
\hline \multicolumn{5}{|l|}{ Ward/district characteristics } \\
\hline Moderate soil constraint & 0.37 & 0.48 & 0.00 & 1.00 \\
\hline Severe/very severe soil constraint & 0.36 & 0.48 & 0.00 & 1.00 \\
\hline District poverty rate & 0.56 & 0.13 & 0.16 & 0.86 \\
\hline District population density (person/km2) & 0.02 & 0.03 & 0.00 & 0.67 \\
\hline \multicolumn{5}{|l|}{ Institutions } \\
\hline FISP access (share in SEA) & 0.36 & 0.24 & 0.00 & 0.95 \\
\hline FRA depots in district (nr.) & 10.57 & 11.17 & 0.00 & 48.00 \\
\hline Extension agents from all sources (nr.) & 0.26 & 0.14 & 0.00 & 0.83 \\
\hline Banks in district $\left(\mathrm{nr} / 100 \mathrm{~km}^{2}\right)$ & 0.03 & 0.07 & 0.00 & 1.44 \\
\hline Tobacco \& Cotton Buyers in District (nr.) & 0.82 & 1.02 & 0.00 & 3.00 \\
\hline
\end{tabular}


societies, as well as household's kinship ties to the chief and the headman of the community as a proxy for social capital. In an average SEA in our sample $50 \%$ of the households participate in any of the groups mentioned above. Almost half of the households have a member with kinship ties to the headman, whereas only $11 \%$ have kinship ties to the chief. Village chiefs in Zambia are representatives of their tribe, whereas headmen are elected by the community and deal with day to day activities in the village. We, therefore, expect the kinship ties to the headmen to be stronger drivers of diversification outcomes. Access to urban centers and markets is one of the frequently cited pull factors for diversification as summarized above. We use the distance to a tarmac road and an established marketplace with many buyers and sellers to test this hypothesis.

Given the role that institutions can play in driving diversification outcomes, we use a set of variables to capture the access to relevant institutions. The Farmer Input Support Subsidy Programme (FISP) is one of the most important programmes in Zambia, accounting for around $60 \%$ of the poverty reduction programme budget of the ministry of agriculture. It provides fertilisers and seeds to "vulnerable but viable" farmers (i.e. those that have the ability to produce at least 0.5 ha of maize) that are members of cooperatives/farmer groups (Mason et al. 2013). Depending on the specific interventions, such programmes can increase or decrease incentives for diversification. In Zambia, only hybrid maize seed was distributed along with fertilizers until 2009, after which rice, sorghum, cotton and groundnuts were included (Mason et al. 2013). We use the share of households in a given SEA who received FISP support to control for the effect of FISP on diversification.

The Food Reserve Agency (FRA) is another important government programme that takes up the rest of the ministry of agriculture's poverty reduction programme budget (Mason et al. 2013). FRA buys maize from farmers at above market prices, aiming to take some of the price risk away from farmers. By making maize incomes less risky, it increases incentives to grow maize, and hence may be expected to decrease crop diversification. However, it may also increase crop diversification if farmers experiment with other crops given the improved security about their maize income, making the a-priori expectations ambiguous. FRA's effect on other indices of diversification is ambiguous as well, as it depends on other factors at play. We use the number of FRA depots in the district to understand these interactions.

Access to credit is very limited in rural Zambia. Only $15 \%$ of households in our sample received a loan from any source during the 2010/11 season. Around $11 \%$ of these were from out-grower Schemes (65\% of all loans in our sample), while only $0.25 \%$ were from commercial banks. Rather than using access to loans as reported by households, which is likely to be endogenous, we use the number of banks per $100 \mathrm{~km}^{2}$ and the number of tobacco and cotton buyers, who are the main suppliers of agricultural credit, to control for the role of credit. Whereas each district has almost one (0.82) cotton or tobacco buyer on average, the average number of banks per $100 \mathrm{~km}^{2}$ is only 0.03 . Last but not least, we also use the number of extension agents in each district to understand the impacts of the availability of the information and technical assistance provided by all available extension sources in driving diversification choices. 
Finally, we include a number of district and ward level variables, primarily to mitigate potential "placement effects" bias on the coefficients for the institutional variables. Thus, we include measures of soil nutrient availability as defined by the HWSD at the ward level (around 70\% of wards have moderate/severe/very severe constraints), and population density and poverty rate (56\%) at the district level from the latest census. ${ }^{11}$

\subsubsection{Malawi}

The Malawian case study uses the Margalef index to measure household livelihood diversification. The Margalef index (MI) is computed according to the following formula: $D_{i}=\frac{\left(S_{i}-1\right)}{\ln \left(N_{i}\right)}$, where $S_{i}$ is the number of farmer-managed units of diversity (i.e. count) for household $i$ and $N_{i}$ is the total population count over all farmermanaged units of diversity. The index has a lower limit of zero if only one unit of diversity is observed. We analyse diversification along three dimensions: crop, labour and income. ${ }^{12}$

We use information on the number of crop types planted and the total area planted during the 2009-10 agricultural season for crop diversification and the time (measured in person-hours per year) allocated to three main working activities (i.e. onfarm, off-farm wage labour and self-employment in household enterprises) for labour diversification. We distinguish between nine main sources of aggregate household income for income diversification index: farm agricultural wage, off-farm non-agricultural wage, on-farm livestock income, on-farm temporary and permanent crop income, on-farm fishery income, income from self-employment in household enterprise, public and private transfers, and income from other non-labour sources.

Figure 4 shows the long term average rainfall and its variability measured by the coefficient of variation and Fig. 5 shows the distribution of diversification patterns across Malawian EAs. We observe that the Northern provinces experience relatively higher levels of average rainfall, as compared to the Southern and Central provinces. While rainfall averages are fairly distinct across the three regions (decreasing from north to south), this is not the case for its variability. While the Northern region has more favourable rainfall conditions, farmers are exposed to significant variability within the region. Farmers in the Southern provinces are particularly vulnerable to weather conditions given the lower amount of average rainfall combined with the highest rainfall variability. Though crop diversification does not show a clear pattern across Malawi, labour diversification tends to be higher in the South. Income diversification is particularly low in the southern-most

\footnotetext{
${ }^{11}$ See CSO Census Web Site for details: http://catalog.ihsn.org/index.php/catalog/4124http://catalog.ihsn.org/index.php/catalog/4124.

${ }^{12}$ Count, Gini-Simpson and Berge-Parker indices were also used in analyses. The results are robust to the choice of index and Margalef index provided the best fit for the data.
} 


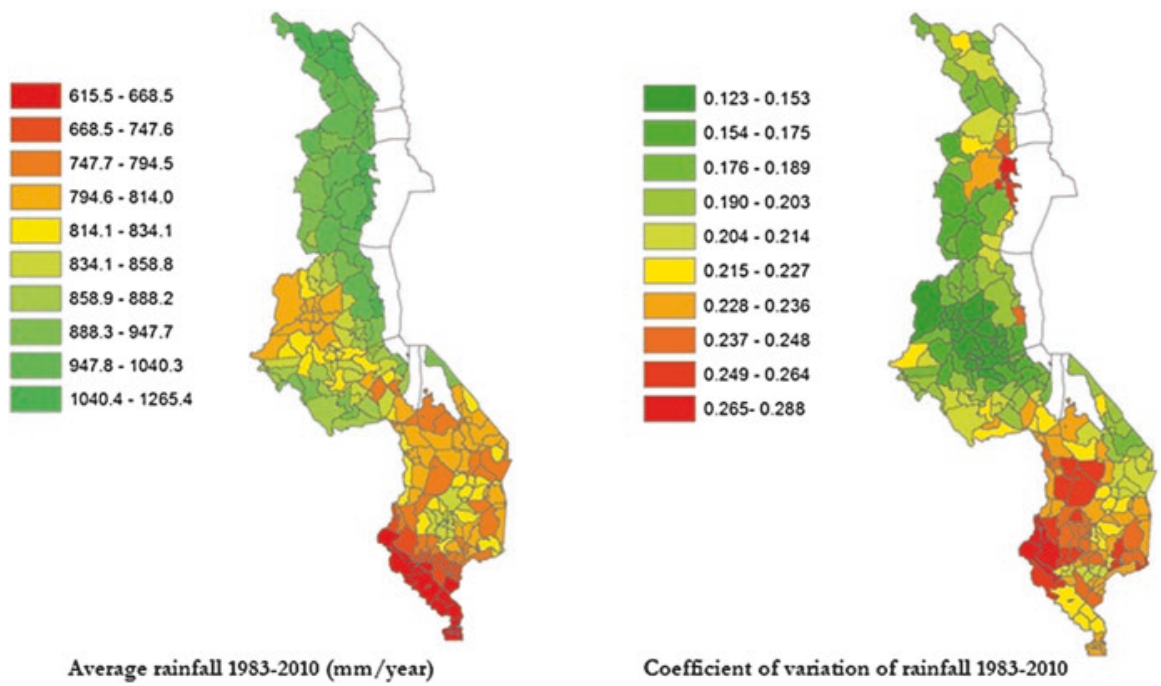

Fig. 4 Average growing season rainfall and its coefficient of variation over 1983-2010

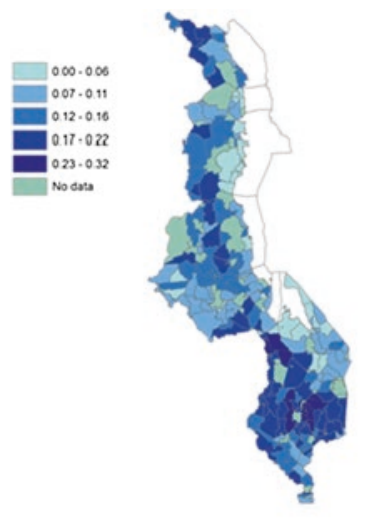

Labour diversification index

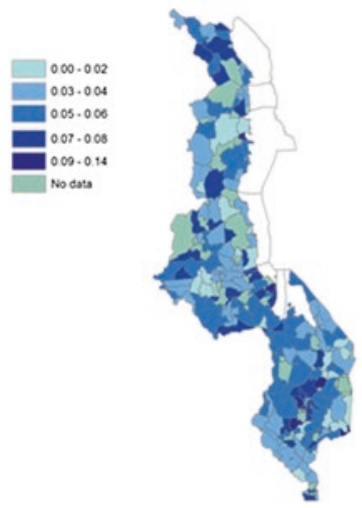

Cropland diversification index

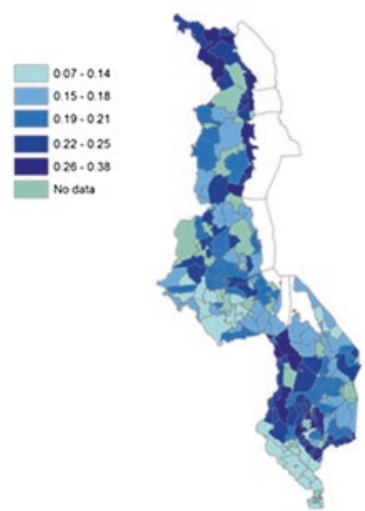

Income diversification index

Fig. 5 Diversification indices by enumeration area (EA)

part of the country and tends to be higher in the central-south as well as in the northern section of the area around Lake Malawi.

Table 4 presents the descriptive statistics of the variables used in the analysis of diversification patterns in Malawi. Similar to the case in Zambia, about $25 \%$ of household heads are female, and wealth indices exhibit a right-skewed distribution indicating a high inequality in the distribution of asset ownership.

The institutional variables we use for the Malawi case study capture issues related to access to information and infrastructure (including markets, roads, irrigation schemes and migration flows), as well as primary administrative data on a num- 
Table 4 Descriptive statistics of control variables (Nr. of observations $=7862$ )

\begin{tabular}{|c|c|c|c|c|}
\hline & Mean & Std. Dev. & Min & Max \\
\hline \multicolumn{5}{|l|}{ Climate variables } \\
\hline CoV of Nov-may rainfall 1983-2010 & 0.211 & 0.035 & 0.123 & 0.288 \\
\hline Average rainfall 1983-2010 (dm) & 8.5 & 1.065 & 6.096 & 12.654 \\
\hline Rainfall anomaly $2009-10$ & -0.086 & 0.092 & -0.369 & 0.2 \\
\hline \multicolumn{5}{|l|}{ Household socio-demographic } \\
\hline Age of household head & 42.965 & 16.738 & 15 & 110 \\
\hline Head is male & 0.748 & 0.434 & 0 & 1 \\
\hline HH size (Adult Equivalent -AE) & 3.886 & 1.828 & 0.97 & 15.68 \\
\hline Education of the head (yrs.) & 4.848 & 3.94 & 0 & 19 \\
\hline Sex ratio & 1.126 & 1.009 & 0 & 8 \\
\hline Dependency ratio & 1.105 & 0.946 & 0 & 11 \\
\hline $\begin{array}{l}\mathrm{Nr} \text { of } \mathrm{HH} \text { members hospitalized in the past } \\
12 \text { months }\end{array}$ & 0.176 & 0.439 & 0 & 7 \\
\hline \multicolumn{5}{|l|}{ Household wealth } \\
\hline Wealth index & -0.502 & 1.37 & -1.45 & 12.053 \\
\hline Agricultural implements access index & 0.374 & 1.378 & -3.272 & 8.265 \\
\hline GPS based land size (acre) & 2.479 & 2.571 & 0 & 44.35 \\
\hline \multicolumn{5}{|l|}{ Community characteristics } \\
\hline In-migration in the community $(1=$ yes $)$ & 0.54 & 0.498 & 0 & 1 \\
\hline Out-migration in the community ( $1=$ yes $)$ & 0.13 & 0.336 & 0 & 1 \\
\hline Irrigation scheme in the community $(1=$ yes $)$ & 0.202 & 0.401 & 0 & 1 \\
\hline Road density in $10 \mathrm{~km}$ radius (' 000 metres) & 9.546 & 2.537 & 0 & 11.274 \\
\hline $\begin{array}{l}\text { Number of months main road was passable by a } \\
\text { truck }\end{array}$ & 9.696 & 3.539 & 0 & 12 \\
\hline $\operatorname{Ln}($ price of fertilizer/price of maize) & 1.121 & 0.836 & -2.708 & 5.339 \\
\hline $\operatorname{Ln}($ wage rate for casual labour/price of maize) & 1.63 & 1.161 & -3.401 & 6.032 \\
\hline \multicolumn{5}{|l|}{ Institutions } \\
\hline $\begin{array}{l}\text { Agricultural extension/development officers in } \\
\text { district (nr) }\end{array}$ & 9.546 & 3.9 & 0 & 22 \\
\hline Microfinance institutions in district (nr.) & 2.813 & 1.639 & 0 & 6 \\
\hline $\begin{array}{l}\text { Fertilizers distributed per household in district } \\
\text { (MT) }\end{array}$ & 1.269 & 0.518 & 0.305 & 2.249 \\
\hline $\begin{array}{l}\text { Ln(MASAF wages paid in 2008/09 season) (mill. } \\
\text { MKW/hh) }\end{array}$ & 0.004 & 0.002 & 0.001 & 0.013 \\
\hline
\end{tabular}

ber of government and non-government institutions relevant for understanding incentives for livelihood diversification strategies. These include the number of agricultural extension and development officers, the number of microfinance projects and institutions and the amount of subsidized fertilizer distributed by district. We also control for the total amount of cash paid out in the 2008/09 season in exchange of labour from the Malawi Social Action Fund (MASAF), which is a government social safety net programme, to control for its effects on diversification 
decisions. By creating a fall-back option, hence a risk-coping mechanism, an active MASAF programme is expected to increase incentives for risk-taking and ex-ante diversification.

\subsection{Econometric Analysis}

\subsubsection{Zambia}

We present the coefficients of the models explaining the determinants of crop, livestock and income source diversification in Table 5. All models are estimated using tobit model specification given the fact that the Gini-Simpson index is bounded between 0 and 1 by definition.

The long term variation in season rainfall measured by the coefficient of variation is positively and significantly correlated with livestock diversification, whereas it is negatively and significantly correlated with income diversification. This suggests that households in areas with highly variable seasonal rainfall perceive livestock diversification as an ex-ante risk management strategy..$^{13}$ Contrary to the expectations, income diversification decreases as rainfall variation increases, suggesting that under highly variable rainfall conditions households revert back to subsistence activities and therefore that pull factor drivers fade away. Current season rainfall deviation from the long term average is not significantly correlated with diversification, suggesting that households are not able respond to immediate shocks to rainfall using the types of diversification analysed here. ${ }^{14}$

In terms of socio-demographic characteristics, female-headed households are less likely to be diversified in terms of crops and livestock but more likely to be diversified in terms of income. These results suggest that female-headed households are not able to take advantage of on-farm diversification opportunities, perhaps due to a gender imbalance in agricultural extension service staff in Zambia (McCarthy, pers. comm.). Greater income diversification in female-headed households may be driven by their higher risk aversion, which leads them to manage risk by engaging in off-farm income opportunities. Education seems to facilitate pull factors into income source diversification by opening up non-farm income opportunities as expected. Of our wealth indicators, land size is positively correlated with crop and livestock diversification but it does not affect income diversification significantly. On the other hand, a higher wealth index - which excludes land - leads to lower crop diversity, but higher livestock and income diversity.

\footnotetext{
${ }^{13}$ Our livestock diversification captures diversification within livestock types. Preliminary analysis of diversification into livestock activities (especially for ruminants) confirms the finding that higher rainfall diversification is significantly and positively correlated with diversification into livestock as well as within livestock activities.

${ }^{14}$ It should be noted here that rainfall anomalies were, for the most part, not very pronounced during the 2010-2011 growing season. Diversification in response to shocks, primarily of income sources, might still occur with greater anomalies.
} 


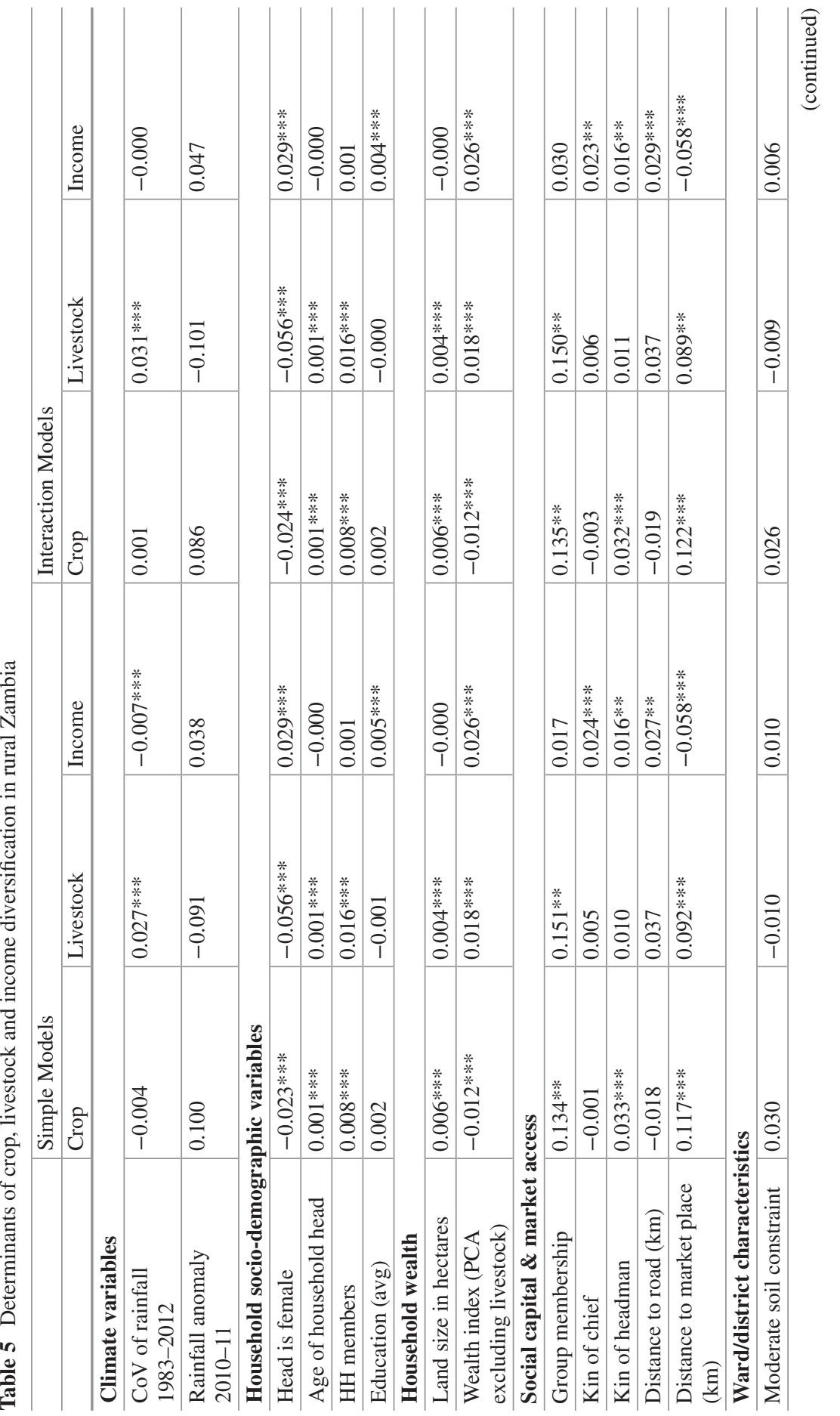




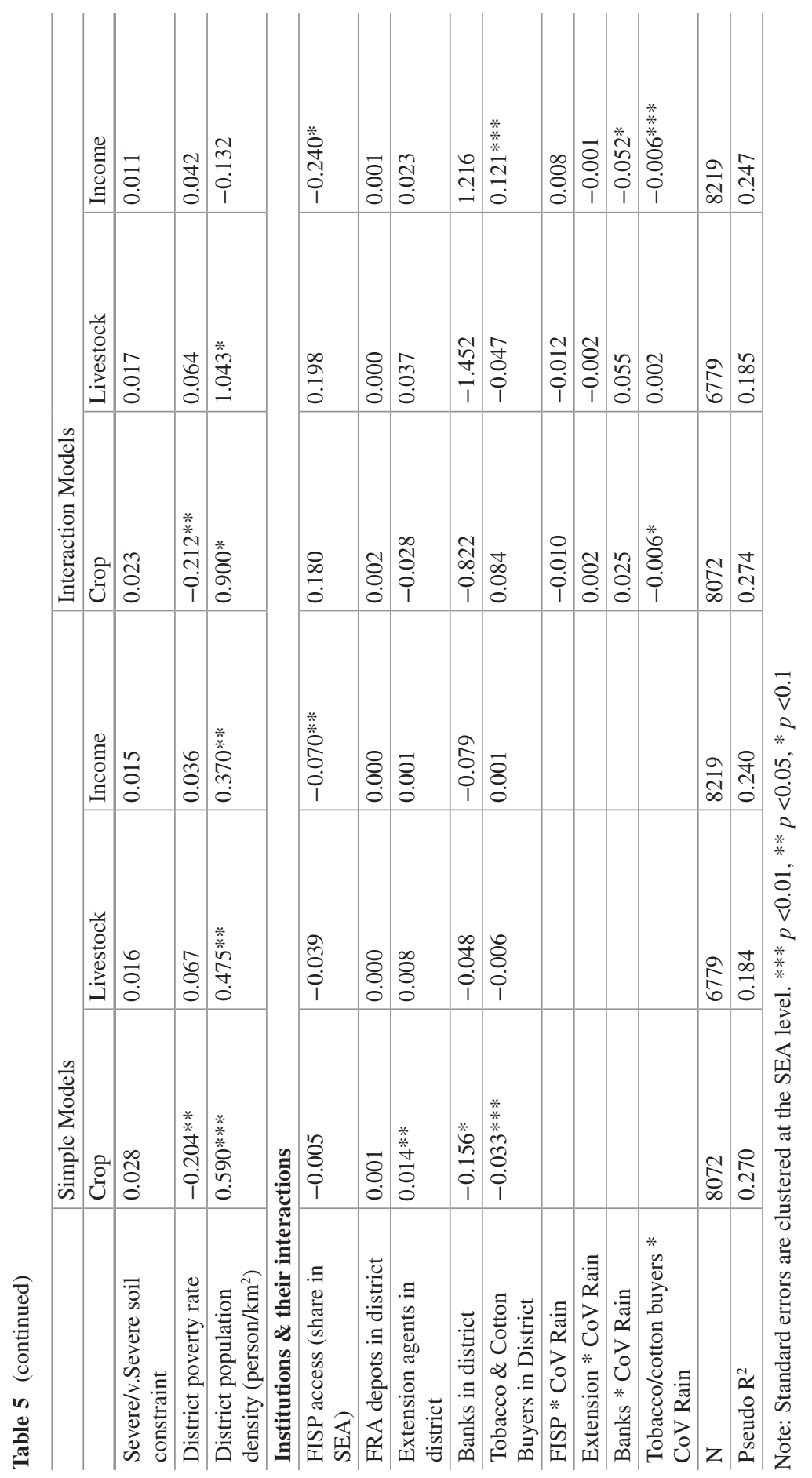


Membership in cooperatives, farmers', women's or savings and loan groups seems to be effective in facilitating crop and livestock diversification, while it is not significantly correlated with income diversification. These groups would need to be supported to increase their connections with other sectors to facilitate different income generating opportunities if they were to be used as policy entry points to Table 5 (continued) increase income diversification as a risk management strategy. On the other hand, having a kinship tie to the village chief or the headman facilitates income diversification.

The coefficients of the distance to market variable suggest that market constraints/transaction costs act as push factors into crop and livestock diversification as households are significantly more likely to be diversified along these dimensions the farther they are from markets. At the same time, income diversification decreases as the distance to market increases as expected. Distance to an all-weather road, on the other hand, is positively correlated with income diversification, suggesting that while local markets give incentives to diversify income sources, having access to urban centers via all-weather roads gives incentives for specialization.

The institutional variables we use cover the most important institutions that shape households' incentives in rural Zambia, ranging from the most important government programmes to support (particularly maize) farmers, to those that address information and credit constraints. Controlling for all other variables, the higher the proportion of households in the SEA that accessed FISP the less diversified are incomes. This provides suggestive evidence that by giving incentives to cultivate maize (and lately legumes as well) FISP decreases incentives to diversify incomes. FISP and FRA do not have a significant impact with any other diversification outcomes, contrary to the expectations.

The availability of extension agents is positively correlated with crop diversification only, suggesting that they mostly assist farmers on crop production in spite of efforts to improve livestock activities in rural Zambia. Credit constraints seem to act as a push factor into crop diversification as households diversify their crops significantly less in districts with more banks and tobacco and cotton buyers that provide credit. The corollary however is not true, as the number of banks and other credit providers are not positively correlated with livestock and income diversification, suggesting that the credit available is only enough to specialize on farm rather than acting as a pull factor into other activities.

Table 5 also presents the results of the models where we included interaction variables between institutional variables and the coefficient of variation in rainfall to investigate whether and how these institutions perform under highly variable rainfall conditions. This is important if these institutions are to act as policy entry points to decrease vulnerability to climate shocks by facilitating diversification. The coefficient of the FISP variable in income diversification model remains significantly negative and is bigger in magnitude, however its interaction with rainfall variation is not significant (although positive) indicating that FISP does not play a different role under highly variable rainfall conditions.

The role of extension also does not differ by rainfall variation, nor does the role of the availability of banks in the district - except for income diversification. The 
interaction term between banks and rainfall variation is negative and significant in the income diversification model, indicating that they do not currently act as catalysts for income diversification where agricultural income is highly vulnerable to rainfall shocks. This is similarly true for tobacco and cotton buyers, as the interaction variable with rainfall variation is also negative and significant. The interaction term models point towards a missed opportunity in terms of using these institutions as channels through which household incentives for diversification can be improved especially under highly unpredictable rainfall conditions in order to decrease vulnerability.

\subsubsection{Malawi}

Table 6 presents the results of crop, labor and income diversification models. We present the results that are estimated using OLS in Asfaw et al. (2015), which are robust to functional form specification. ${ }^{15}$ We find that the coefficient of variation of rainfall is positively correlated with all three diversification indices indicating that rainfall variability is a push factor into these dimensions of diversification in Malawi. Higher average rainfall is associated with greater diversification in income, but not for crop or labour diversification as expected, indicating that more favourable average rainfall conditions are a pull factor that enables households to secure income from a wider range of sources. A higher rainfall anomaly experienced in the last season reduces income diversification, indicating that households cannot respond quickly to recent shocks. It is important to note that, as in Zambia, the anomaly was mostly moderate during that particular season, suggesting that households are not pursuing income or labour diversification strategies to cope with moderate shocks.

Male-headed households have higher total labour diversification, indicating a potential barrier in labor markets for female headed households. Unlike in Zambia, female headed households are more likely to diversify their crops, but income diversification is higher in female headed households in both countries providing suggestive evidence to support the findings in literature on higher female-risk aversion (Hartog et al. 2002; Borghans et al. 2009). Crop diversification increases with land size and decreases with wealth index just as in Zambia. The existence of an irrigation scheme in the community, which can be associated with less risky crop production, decreases labour and crop diversification, as expected. The number of months during which the main road was passable by a truck is positively and significantly correlated with in labour and income diversification, indicating that lower transaction costs favour these types of diversification.

With respect to institutions, results show that the availability of extension has a positive impact on all diversification measures, indicating that extension information enables pull factors into both on- and off-farm opportunities. Availability of

\footnotetext{
${ }^{15}$ Margalef index has a lower limit of 0 and (unlike the Gini-Simpson index) is not bounded from above. We compared the OLS results with the results of a tobit specification and confirmed that the results are robust. We present the results as in Asfaw et al. (2015) here, as the purpose of this chapter is to synthesize evidence rather than present new results in the case of Malawi.
} 
Table 6 Determinants of crop, labour and income diversification in rural Malawi

\begin{tabular}{|c|c|c|c|}
\hline & Crop & Labour & Income \\
\hline \multicolumn{4}{|l|}{ Climate variables } \\
\hline CoV of rainfall $1983-2010$ & $3.946 * * *$ & $1.570 * * *$ & $3.438 * * *$ \\
\hline Average rainfall 1983-2010 (dm) & 0.005 & 0.003 & $0.230 * * *$ \\
\hline Rainfall anomaly $2009-10$ & 0.352 & 0.079 & $-0.755^{* * *}$ \\
\hline \multicolumn{4}{|l|}{ Household socio-demographic } \\
\hline Age of household head & $-0.003 * * *$ & $-0.003 * * *$ & 0 \\
\hline Head is male & $-0.115 * * *$ & $0.048 * *$ & $-0.066 * *$ \\
\hline Household size & 0.004 & $0.019 * * *$ & $0.065 * * *$ \\
\hline Household head highest level of education & $0.019 * * *$ & $0.017 * * *$ & $0.013 * * *$ \\
\hline Sex ratio & -0.008 & -0.003 & 0 \\
\hline Dependency ratio & $0.026^{*}$ & -0.002 & 0.005 \\
\hline $\begin{array}{l}\text { HH members hospitalized in the past } \\
12 \text { months }\end{array}$ & 0.021 & $0.046^{* *}$ & $0.100 * * *$ \\
\hline
\end{tabular}

\section{Household wealth}

\begin{tabular}{l|l|l|l}
\hline Wealth index & $-0.048 * * *$ & $0.088^{* * * *}$ & $-0.026 * *$ \\
\hline Agricultural implements access index & $0.133 * * *$ & 0.01 & $0.170^{* * *}$ \\
\hline GPS based land size (acre) & $0.189 * * *$ & 0.001 & $0.067 * * *$ \\
\hline Coo
\end{tabular}

\section{Community characteristics}

\begin{tabular}{|c|c|c|c|}
\hline In migration in the community $(1=$ yes $)$ & -0.084 & 0.029 & 0.012 \\
\hline Out migration in the community ( $1=$ yes $)$ & 0.004 & 0.037 & -0.026 \\
\hline $\begin{array}{l}\text { Irrigation scheme in the community } \\
(1=\text { yes })\end{array}$ & $-0.140 * * *$ & $-0.052 * *$ & -0.072 \\
\hline Road density in $10 \mathrm{~km}$ radius ('000 metres) & 0.01 & 0.004 & 0 \\
\hline $\begin{array}{l}\text { Number of months road was passable by a } \\
\text { lorry }\end{array}$ & -0.004 & $0.007 * *$ & $0.010^{*}$ \\
\hline $\operatorname{Ln}$ (price of fertilizer/price of maize) & $0.134 * * *$ & 0.027 & $0.126^{* * *}$ \\
\hline $\begin{array}{l}\operatorname{Ln}(\text { wage rate for casual labour/price of } \\
\text { maize) }\end{array}$ & $-0.070 * * *$ & -0.01 & $-0.147 * * *$ \\
\hline \multicolumn{4}{|l|}{ Institutions } \\
\hline $\begin{array}{l}\text { Extension/development officers in district } \\
\text { (nr.) }\end{array}$ & $0.017 * * *$ & $0.009 * * *$ & $0.022 * * *$ \\
\hline Fertilizers distributed/hh in district (MT) & $0.139 * * *$ & -0.021 & $0.110 * *$ \\
\hline Microfinance institutions in district (nr.) & $-0.105 * * *$ & $0.019 * *$ & $-0.046 * * *$ \\
\hline Ln(MASAF wages paid in 2008-09 season) & $-26.823 * * *$ & 1.837 & 12.854 \\
\hline Constant & 0.138 & -0.196 & $-1.525 * * *$ \\
\hline Observations & 7255 & 7862 & 7768 \\
\hline R-squared & 0.26 & 0.082 & 0.20 \\
\hline
\end{tabular}

Note: Standard errors are clustered at the EA level. *** $p<0.01$, ** $p<0.05$, * $p<0.1$

fertilizer subsidies per capita also increases cropland and income diversification. Availability of microfinance institutions and social safety nets, both of which can help farmers to cope with poor weather ex post, reduce cropland diversification. Credit availability also reduces income diversification but increases labour diversi- 
fication, indicating that although it helps farmers secure more diverse set of working activities, this comes at the expense of the diversity in other income sources captured by our index. ${ }^{16}$

As with Zambia, we have done the analysis including interaction terms between our institutional variables and the $\mathrm{CoV}$ of rainfall (results not presented here). In this case, none of the interaction terms were statistically significant, indicating that though the institutions lead to greater diversification on average, they are not performing relatively better in enabling diversification in high rainfall risk environments.

\section{Diversification and Vulnerability}

Linking the diversification model results with household vulnerability outcomes empirically is inherently fraught with endogeneity problems (due to both reverse causality and selection/omitted variables bias) as household diversification outcomes are the results of actions taken in response to vulnerability of income/consumption under imperfect market conditions and risk aversion. Therefore an analysis of the dynamic concept of vulnerability - however defined - as a function of diversification indices using cross-sectional data would very likely produce biased results. Here we present only a descriptive analysis of the correlations between vulnerability indicators in our data and diversification measures.

\subsection{Zambia}

We use three variables as indicators of vulnerability in Zambia: the logarithm of income per capita and its variance, and the number of months the household did not have enough food during the survey year. The levels of a welfare outcome (consumption or assets) and its variance are used as the components of vulnerability in the vulnerability to poverty literature (Christiaensen and Subbarao 2005; Chaudhuri et al. 2002). RALS data does not have a detailed consumption module, therefore we use total income and its variance estimated from a regression of income determinants as components of vulnerability to income poverty. We also use the income poverty line from the Zambian Living Conditions Monitoring Report (CSO 2010) to calculate the Foster-Greer-Thorbecke (FGT) poverty measures.

Table 7 reports the simple correlations between diversification measures and vulnerability indicators. Income per capita is positively, and its variance is negatively, correlated with all diversification measures as expected. Number of food deficit months on the other hand is positively correlated with income diversification,

\footnotetext{
${ }^{16}$ The income diversification includes five different on-farm income sources, whereas labour diversification only has one on-farm labour category.
} 
Table 7 Correlation coefficients between diversification and vulnerability indicators

\begin{tabular}{l|l|l|l|l|l|l}
\hline & $\begin{array}{l}\text { Crop } \\
\text { Div. }\end{array}$ & $\begin{array}{l}\text { Livestock } \\
\text { Div. }\end{array}$ & $\begin{array}{l}\text { Income } \\
\text { Div. }\end{array}$ & $\begin{array}{l}\text { Income per } \\
\text { capita (ln.) }\end{array}$ & $\begin{array}{l}\text { Variance of } \\
\text { Income }\end{array}$ & $\begin{array}{l}\text { Food deficit } \\
\text { months }\end{array}$ \\
\hline Crop div. & 1 & & & & & \\
\hline Livestock div. & 0.06 & 1 & & & & \\
\hline Income div. & -0.10 & 0.05 & 1 & & & \\
\hline $\begin{array}{l}\text { Income per } \\
\text { capita (ln.) }\end{array}$ & 0.05 & 0.09 & 0.11 & 1 & & \\
\hline $\begin{array}{l}\text { Variance of } \\
\text { Income }\end{array}$ & -0.14 & -0.03 & -0.01 & 0.00 & 1 & \\
\hline $\begin{array}{l}\text { Food deficit } \\
\text { months }\end{array}$ & -0.04 & -0.13 & 0.05 & -0.21 & 0.02 & 1 \\
\hline
\end{tabular}

Table 8 Food deficit categories and diversification

\begin{tabular}{l|l|l|l}
\hline Food deficit & Crop Div. & Livestock Div. & Income Div. \\
\hline Less than 3 months & 0.41 & 0.15 & 0.29 \\
\hline 3-6 months & 0.37 & 0.09 & 0.33 \\
\hline More than 6 months & 0.35 & 0.09 & 0.33 \\
\hline Total & 0.41 & 0.14 & 0.30 \\
\hline
\end{tabular}

suggesting that income diversification may act as a coping strategy to deal with transient shocks.

In order to unpack the relationship between vulnerability to food shortages and diversification, Table 8 reports the average diversification indices by different categories of food deficit months. Households that had less than 3 months of food deficit have the highest crop and livestock diversification and the lowest income diversification. On the other hand, those who had more than 6 months of food deficit have the lowest crop and livestock diversification and the highest income diversification, providing further evidence that income diversification results from push factors in rural Zambia, at least in terms of food availability. That income diversification is a coping strategy rather than voluntary choice in rural Zambia is a finding supported by earlier descriptive literature (Karttunen 2009). Higher incomes per capita, then, do not necessarily translate into the ability to purchase the same amount of food as is available to households with larger landholdings and thus their own production. Given the subjective nature of this result, however, more research is needed to establish this correlation.

Finally, we look at the distribution of diversification and vulnerability measures across AERs, which shape the thinking about climate change and its impacts on agriculture and livelihoods in Zambia (Table 9).

AER I, which is the region with the lowest rainfall that also has the highest variability across years, has the lowest crop diversification and highest income diversification. It also has the second lowest income per capita with the highest variance as well as highest rate and depth of poverty. Given the importance of livestock in the incomes of households in AER I and the fact that rainfall is projected to decrease with increased unpredictability, combined with our finding that increased rainfall 
Table 9 Diversification, vulnerability and poverty by AER

\begin{tabular}{l|l|l|l|l|l|l|l|l}
\hline AER & $\begin{array}{l}\text { Crop } \\
\text { Div. }\end{array}$ & $\begin{array}{l}\text { Live- } \\
\text { stock } \\
\text { Div. }\end{array}$ & $\begin{array}{l}\text { Income } \\
\text { Div. }\end{array}$ & $\begin{array}{l}\text { Income per } \\
\text { capita }\end{array}$ & $\begin{array}{l}\text { Var. of } \\
\text { Income }\end{array}$ & $\begin{array}{l}\text { Food } \\
\text { deficit } \\
\text { months }\end{array}$ & $\begin{array}{l}\text { Poverty } \\
\text { Rate }\end{array}$ & $\begin{array}{l}\text { Depth of } \\
\text { Poverty }\end{array}$ \\
\hline I & 0.28 & 0.17 & 0.34 & $137,262.83$ & 0.76 & 1.75 & 0.79 & 0.62 \\
\hline IIa & 0.40 & 0.18 & 0.31 & $170,519.35$ & 0.62 & 1.23 & 0.70 & 0.57 \\
\hline IIb & 0.39 & 0.05 & 0.28 & $135,814.12$ & 0.69 & 3.35 & 0.79 & 0.59 \\
\hline III & 0.44 & 0.11 & 0.29 & $168,005.51$ & 0.60 & 1.52 & 0.67 & 0.52 \\
\hline Total & $\mathbf{0 . 4 1}$ & $\mathbf{0 . 1 4}$ & $\mathbf{0 . 3 0}$ & $\mathbf{1 6 3 , 9 3 5 . 8 4}$ & $\mathbf{0 . 6 3}$ & $\mathbf{1 . 5 7}$ & $\mathbf{0 . 7 0}$ & $\mathbf{0 . 5 5}$ \\
\hline
\end{tabular}

variation increases livestock diversification indicates that policies that can facilitate diversification under the predicted impacts of climate change are needed to address the compounded issues of poverty and vulnerability in the region. This finding becomes more important taking into account that income diversification is negatively correlated with income and is a coping strategy for the poorest and most food insecure in this region.

AER IIb also stands out with its low incomes with high variance, high average food deficit months and poverty rate, and lowest livestock and income diversification. Projected impacts of climate change in this region (including decreased rainfall and increased temperatures and unpredictability) underline the importance of actions to improve the capacity to diversify income sources and, where possible, integration of livestock into agriculture.

\subsection{Malawi}

As for the Zambia analysis, we conclude our analysis with an exploratory investigationintothecorrelationsbetweendiversificationand variousconsumption/vulnerability indicators. Given the detailed consumption module in IHS data, we calculate the main components of vulnerability (levels and variance) using consumption data (Christiaensen and Subbarao 2005; Chaudhuri et al. 2002). We also use other poverty indicators such as the different types of FGT indices (i.e. poverty rate, depth of poverty and severity of poverty).

All diversification indices are negatively correlated with the variance of consumption. While labor and income diversification are also positively correlated with expected consumption, this correlation is negative for crop diversification, suggesting that diversification of labour and income are driven by pull factors, whereas crop diversification is mainly a result of push factors. The latter indicates that crop diversification is a risk management strategy, leading to lower, but more stable, crop production. All three diversification strategies are negatively correlated with all poverty indicators, providing suggestive evidence that they have potential to contribute to food security and adaptation (Table 10).

To conclude our exploratory analysis we look at the heterogeneity of poverty and diversification strategies across the three regions of the country. The table confirms 
Table 10 Correlation coefficients between diversification and vulnerability indicators

\begin{tabular}{l|l|l|l|l|l|l|l|l}
\hline & $\begin{array}{l}\text { Labor } \\
\text { Div. }\end{array}$ & $\begin{array}{l}\text { Income } \\
\text { Div. }\end{array}$ & $\begin{array}{l}\text { Crop } \\
\text { Div. }\end{array}$ & $\begin{array}{l}\text { Var. of } \\
\text { Consump- } \\
\text { tion }\end{array}$ & $\begin{array}{l}\text { Expected } \\
\text { Consump- } \\
\text { tion }\end{array}$ & $\begin{array}{l}\text { Poverty } \\
\text { rate }\end{array}$ & $\begin{array}{l}\text { Poverty } \\
\text { gap }\end{array}$ & $\begin{array}{l}\text { Poverty } \\
\text { severity }\end{array}$ \\
\hline Labor div. & 1.00 & & & & & & & \\
\hline Income div. & 0.30 & 1.00 & & & & & & \\
\hline Crop div. & 0.03 & 0.25 & 1.00 & & & & & \\
\hline $\begin{array}{l}\text { Variance of } \\
\text { consum } \\
\text { ption }\end{array}$ & -0.02 & -0.09 & -0.10 & 1.00 & & & & \\
\hline $\begin{array}{l}\text { Expected } \\
\text { consump } \\
\text { tion }\end{array}$ & 0.17 & 0.01 & -0.03 & -0.04 & 1.00 & & & \\
\hline Poverty rate & -0.15 & -0.08 & -0.06 & 0.02 & -0.51 & 1.00 & & \\
\hline $\begin{array}{l}\text { Poverty gap } \\
-0.15\end{array}$ & -0.14 & -0.08 & 0.06 & -0.52 & 0.77 & 1.00 & \\
\hline $\begin{array}{l}\text { Poverty } \\
\text { severity }\end{array}$ & -0.12 & -0.15 & -0.09 & 0.07 & -0.46 & 0.59 & 0.95 & 1.00 \\
\hline
\end{tabular}

Table 11 Diversification, vulnerability and poverty by region

\begin{tabular}{l|r|r|r|r}
\hline Variable & North & Central & \multicolumn{1}{l}{ South } & \multicolumn{1}{l}{ Total } \\
\hline Labor div. & 0.043 & 0.041 & 0.044 & 0.043 \\
\hline Income div. & 0.228 & 0.186 & 0.198 & 0.199 \\
\hline Crop div. & 0.125 & 0.133 & 0.168 & 0.148 \\
\hline Variance of consumption & 0.250 & 0.252 & 0.227 & 0.240 \\
\hline Expected consumption & 10.696 & 10.804 & 10.646 & 10.710 \\
\hline Poverty rate & 0.525 & 0.420 & 0.543 & 0.495 \\
\hline Poverty gap & 0.184 & 0.139 & 0.202 & 0.176 \\
\hline Poverty severity & 0.086 & 0.063 & 0.098 & 0.083 \\
\hline
\end{tabular}

that Malawi is a rather homogenous country (as opposed to Zambia) with similar distributions in these variables across the three regions. The southern region is slightly more diversified in terms of labor and crops, and is slightly lower levels of consumption than the other two regions, although it's more stable. The central region, on the other hand, is less diversified and has lower FGT poverty measures, but presents higher levels as well as variability of consumption (Table 11).

\section{Synthesis of Cross-Country Evidence and Conclusions}

The two case studies presented in this chapter demonstrate that diversification is clearly an adaptation response as long term trends in climatic shocks have a significant effect on livelihood diversification, albeit with different implications. Whereas the long term variation in growing period rainfall acts as a push factor into all three types of diversification in Malawi, it only acts as a push factor into livestock 
diversification in Zambia. The findings in Malawi are as expected based on both theoretical and empirical literature predicting an increase in diversification with increases in riskiness in agricultural activity (Barrett et al. 2001a; Reardon et al. 2007; Brown 2008). The effect of this variable on income diversification has the opposite sign in Zambia, where households revert back to subsistence crop production activities instead of diversifying incomes. The fact that this effect of rainfall variation disappears when we control for its interactions with institutional variables suggests that a focus on on-farm income generation is facilitated by FISP and credit access from various sources that incentivize agricultural production - potentially at the expense of long term livelihood resilience. Diversification into and within livestock activities has long been promoted in Zambia as a way to address vulnerability, and our results show that rainfall stress increases the incentives to do so. Further research on the implications of these activities for vulnerability based on panel data is needed to devise targeted policies to support livelihoods under climate stress.

Female headed households are found to be more likely to have diversified income sources in both countries, which seems to be driven by women's higher risk aversion observed in the literature. Whereas female headed households seem not to be able to benefit from pull factors into crop diversification in Zambia, those in Malawi are more diversified in terms of crops. Crop diversification in Malawi, however, is potentially driven by push factors as suggested by descriptive analysis, indicating that female headed households are likely to be disadvantaged in terms of benefiting from pull factors there as well.

Higher education acts as a pull factor into income diversification in both countries consistent with the literature (Reardon et al. 2007 and the references within). The more members a household has, the more likely it is to have higher crop and livestock diversification in Zambia, and higher labour and income diversification in Malawi. These differences suggest structural differences between the rural labour markets and other income generating activities in these countries. Perhaps due to its size, Malawi seems to have more active pull factors into diversification beyond the farm than Zambia. This finding is also supported by the positive and significant correlation between labour and income diversification and the number of months the road was passable by a truck in Malawi, whereas income diversification increases with distance to an all-weather road in Zambia.

Households with larger land size are significantly more likely to diversify their crops suggesting potential barriers to diversification for smallholders. Better targeting for smallholders in crop diversification interventions would be needed, especially in cases where climate variability is expected to negatively affect the subsistence crop production they heavily depend on. Another indicator of wealth measured by the wealth index has the same negative correlation with crop diversification in both countries, whereas it correlates with income diversification in opposite ways in Malawi and Zambia. Households with higher wealth seem to specialize in a couple of income generating activities in Malawi, but they diversify income sources more in Zambia. Whereas this finding in Zambia is consistent with most previous findings in Africa (Reardon 1997; Barrett and Reardon 2000; Burke and Lobell 2010; Martin and Lorenzen 2016), Malawi seems to follow the evidence 
from Latin America, which is explained by the availability of low-barrier-to-entry labor-intensive jobs, high population density and unequal landholdings in the literature (Reardon et al. 2000).

With regard to institutions, we find that access to extension agents positively and significantly correlates with crop diversification in both countries, underlining the role of extension in promoting more resilient farming technologies in rural Zambia and Malawi. Fertilizer subsidies are among the most important agricultural policies in both countries and we find that they significantly affect incentives for income diversification - though in opposing ways. Whereas income diversification is positively correlated with subsidized fertilizer distribution in Malawi, this effect is negative in Zambia (more so under average rainfall variability). If income diversification is a policy goal to decrease vulnerability to climate change as stated in recent national policies and programmes, research to better understand how these subsidy programmes can be reformed to achieve this goal is necessary. Lastly, access to credit is found to decrease crop diversification, especially under highly variable rainfall conditions in Zambia, which requires special attention in the context of climate change as rural development policies strive to improve the functioning of credit markets.

The two case studies in this chapter document distinct ways in which incentives for livelihood diversification (measured along different dimensions) are shaped by increased variability in rainfall and rural institutions. The results also demonstrate that diversification can be an effective adaptation response and the risk-return tradeoffs are not as pronounced as might be expected. The differences across types of diversification and drivers in shaping the tradeoffs and synergies underline the importance of identifying and promoting the desirable diversification options for specific country circumstances. Given the predicted impacts of climate change on rainfall patterns, the implied changes in livelihood diversification merit special attention as part of a climate smart approach to agricultural development. Diversification has the potential to improve food security as well as contribute to adaptation efforts by decreasing vulnerability; however disentangling these multidimensional and dynamic relationships requires panel data analyses planned for future research. Establishing causality among the multiple diversification strategies, institutions and climatic shocks using cross-sectional data is not feasible, hence the results presented here should be interpreted with this caveat in mind.

\section{References}

Adger, W. N. (1999). Social vulnerability to climate change and extremes in coastal Vietnam. World Development, 27, 249-269. doi:10.1016/S0305-750X(98)00136-3

Adger, W. N., Arnell, N. W., \& Tompkins, E. L. (2005). Successful adaptation to climate change across scales. Global Environmental Change, 15, 77-86. doi:10.1016/j.gloenvcha.2004.12.005

Alderman, H. and D.E. Sahn.1989. "Understanding the Seasonality of Employment, Wage, and Income," Ch.6 in D.E. Sahn (ed.), Seasonal Variability in Third World Agriculture: The Consequences for Food Security, Baltimore, MD: John Hopkins Press, pp. 81-106. 
Alderman, H. and Paxson, C. 1992. "Do the poor insure? A synthesis of the Literature on Risk and Consumption in Developing Countries," Ch. 3 in Bacha, E. L. (ed.), Economics in a Changing World, eds. Vol. 4: Development, Trade and the Environment, S. Martin's Press, pp. 48-78.

Arslan, A., McCarthy, N., Lipper, L., Asfaw, S. Cattaneo, A. Kokwe, M. 2015. "Climate Smart Agriculture? Assessing the Adaptation Implications in Zambia," Journal of Agricultural Economics, 66, 3, 753-780.

Asfaw, S., McCarthy, N., Arslan, A., Lipper, L. and Cattaneo, A. (2015): Diversification, Climate risk and Vulnerability to Poverty: Evidence from Rural Malawi. FAO-ESA Working Paper $15-02$.

Asmah, E.E. 2011. Rural livelihood diversification and agricultural household welfare in Ghana. Journal of Development and Agricultural Economics 3(7): 325-334.

Babatunde, R.O. \& Qaim, M. 2009. Patterns of income diversification in rural Nigeria: determinants and impacts. Quarterly Journal of International Agriculture 48: 305-320.

Bandyopadhyay, S. \& Skoufias, E. 2013. Rainfall variability, occupational choice, and welfare in rural Bangladesh. Policy Research Working Paper 6134. Washington, DC, World Bank.

Barrett, C.B. \& Reardon, T. 2000. Asset, activity, and income diversifications among African agriculturalist: Some practical issues. Project report. USAID BASIS CRSP.

Barrett, C.B., Reardon, T. \& Webb, P. 2001a. Nonfarm income diversification and household livelihood strategies in rural Africa: concepts, dynamics and policy implications. Food Policy 26(4): 315-331.

Barrett, C.B., Bezuneh, M. \& Aboud, A. 2001b. Income diversification, poverty traps and policy shocks in Côte d'Ivoire and Kenya. Food Policy 26(4): 367-384.

Binswanger, H.P. 1983. "Agricultural Growth and Rural Non-farm Activities," Finance \& Development, pp. 38-40.

Boko, M., I. Niang, A. Nyong, C. Vogel, A. Githeko, M. Medany, B. Osman-Elasha, R. Tabo \& P. Yanda 2007. Africa. In M.L. Parry, O.F. Canziani, J.P. Palutikof, P.J. van der Linden \& C.E. Hanson, eds. Climate change 2007: Impacts, adaptation and vulnerability. Contribution of Working Group II to the Fourth Assessment Report of the Intergovernmental Panel on Climate Change. Cambridge University Press, Cambridge, UK, 433-467.

Borghans, L., Golsteyn, B. H. H., Heckman, J. J. and Meijers, H. 2009. "Gender Differences in Risk Aversion and Ambiguity Aversion," Journal of the European Economic Association, MIT Press, 7(2-3): 649-658.

Bradshaw, B., Dolan, A. \& Smit, B. 2004. Farm-level adaptation to climatic variability and change: crop diversification in the Canadian prairies. Climatic Change 67(1): 119-141.

Brown, M. E. 2008. "The Impact of Climate Change on Income Diversification and Food Security in Senegal," Chapter 3 in Land Change Science in the Tropics: Changing Agricultural Landscapes, pp. 33-52, Springer US, doi: 10.1007/978-0-387-78864-7_3

Bryceson, D. 1996. Deagrarianization and rural development in Sub-Saharan Africa: A sectoral perspective. World Development 24(1): 97-111.

Bryceson, D. 1999. African rural labour, income diversification and livelihood approaches: A longterm development perspective. Review of African Political Economy 26(80): 171-189.

Burke M. and Lobell, D. 2010. "Food Security and Adaptation to Climate Change: What Do We Know?" Chapter 8 in Climate Change and Food Security, D. Lobell and M. Burke (eds.), Advances in Global Change Research 37, pp. 133-153, doi: 10.1007/978-90-481-2953-9_8

Campbell, B. M., Thornton, P., Zougmoré, R., van Asten, P. and Lipper, L. 2014. "Sustainable intensification: What is its role in climate smart agriculture?" Current Opinion in Environmental Sustainability, 8:39-43. doi:10.1016/j.cosust.2014.07.002

Cavatassi, R. Lipper, L. and Narloch, U. 2011. "Modern variety adoption and risk management in drought prone areas: Insights from the sorghum farmers of eastern Ethiopia." Agricultural Economics; 42(3):279-292. doi:10.1111/j.1574-0862.2010.00514.x

Cavatassi, R., Lipper, L. and Winters, P. 2012. "Sowing the seeds of social relations: social capital and agricultural diversity in Hararghe, Ethiopia," Environment and Development Economics 17(5): 547-578. doi:10.1017/ S1355770X12000356 
Challinor, A., Simelton, W., Fraser, E., Hemming, D., Collins, C. (2010) Increased crop failure due to climate change: assessing adaptation options using models and socio-economic data for wheat in China. Environmental Research Letters 5(3): 034012.

Chapoto, A., Banda, D., Haggblade, S. and Hamukwala, P. 2011. "Factors Affecting Poverty Dynamics in Rural Zambia." Food Security Research Project, Working Paper No. 55, Lusaka.

Chaudhuri, S., Jalan, J. \& Suryahadi, A. 2002. Assessing household vulnerability to poverty from cross-sectional data: A methodology and estimates from Indonesia. Discussion Paper No. 010252, New York, USA, Columbia University.

Chinsinga, B. 2012. The political economy of agricultural policy processes in Malawi: A case study of the fertilizer subsidy programme. Future Agricultures Consortium Working Paper 39. Brighton, UK.

Christiaensen, L. \& Subbarao, K. 2005. Towards an understanding of household vulnerability in rural Kenya. Journal of African Economies 14(4): 520-558.

Davis, B., Winters, P., Carletto, G., Covarrubias, K., Quiñones, E.J., Zezza, A. \& DiGiuseppe, S. 2010. A cross-country comparison of rural income generating activities. World Development 38(1): 48-63.

Davies, S. and Hossain, N. 1997. "Livelihood Adaptation, Public Action and Civil Society: A Review of the Literature," IDS Working Paper No.57, Brighton: Institute of Development Studies.

Deichmann, U., Shilpi, F. \& Vakis, R. 2008. Spatial specialization and farm-nonfarm linkages. World Bank Policy Research Working Paper No. 4611. Washington, DC, World Bank.

De Janvry, A., M. Fafchamps and E. Sadoulet. 1991. Peasant household behaviour with missing markets - some paradoxes explained, Economic Journal 101: 1400-1417.

Delgado, C. \& Siamwalla, L. 1999. Rural economy and farm diversification developing countries. In G. H. Peters, \& J. von Braun, eds. Food security, diversification and resource management, refocusing the role of agriculture. International Associations of Agricultural Economists. Brookfield, USA, Ashgate.

Denning, G., Kabambe, P., Sánchez, P., Malik, A., Flor, R., Harawa, R., Nkhoma, P., Zamba, C., Banda, C., Magombo, C., Keating, M., Wangila, J. \& Sachs, J. 2009. Input subsidies to improve smallholder maize productivity in Malawi: Toward an African green revolution. PLoS Biology 7(1): 2-10.

Di Falco, S. \& Chavas, J.P. 2009. On crop biodiversity, risk exposure, and food security in the highlands of Ethiopia. American Journal of Agricultural Economics 91(3): 599-611.

Dimova, R. \& Sen, K. 2010. Is household income diversification a means of survival or a means of accumulation? Panel data evidence from Tanzania. Brooks World Poverty Institute Working Paper No. 12210. BWPI, University of Manchester.

Ellis, F. 1998. Household strategies and rural livelihood diversification. Journal of Development Studies 35(1): 1-38.

Ersado, L. 2003. Income diversification in Zimbabwe: Welfare implications from Urban and Rural Areas., FCND Discussion Paper No. 152. International Food Policy Research Institute, Food Consumption and Nutrition Division.

Fafchamps, M. \& Shilpi, F. 2003. The spatial division of labour in Nepal. The Journal of Development Studies 39(6): 23-66.

Fafchamps, M. \& Shilpi, F. 2005. Cities and specialisation: evidence from South Asia. The Economic Journal 115(503): 477-504.

FAO. 2010. "Climate-Smart" Agriculture. Policies, Practices and Financing for Food Security, Adaptation and Mitigation. Food and Agriculture Organization of the United Nations, Rome, Italy.

FAO 2013. Climate-Smart Agriculture Sourcebook. Food and Agriculture Organization of the United Nations, Rome, Italy.FAO, IFAD and WFP (Food and Agriculture Organization of the United Nations, International Fund for Agricultural Development and World Food Programme). 2014. State of Food Insecurity in the World 2014: Strengthening the enabling environment for food security and nutrition. FAO, Rome. 
Folke, C. (2006). Resilience: The emergence of a perspective for social-ecological systems analyses. Global Environmental Change, 16, 253-267. doi:10.1016/j.gloenvcha.2006.04.002

Foresight International Dimensions of Climate Change (2011). Final Project Report. The Government Office for Science, London.

GoM (Government of Malawi) 2006. Malawi growth and development strategy 2006-2011, Ministry of Economic Planning and Development, Lilongwe.

GoM. 2008. Agricultural Development Programme (ADP), Lilongwe, Ministry of Agriculture and Food Security.

Hartog, J., Ferrer-i-Carbonell, A. and Jonker, N. 2002. "Linking Measured Risk Aversion to Individual Characteristics." Kyklos, 55, 3-26.

IHS (Integrated Household Survey, Malawi). 2012. Household socio-economic characteristics report. National Statistical Office, Lilongwe, Malawi.

IPCC. (2007). Climate Change 2007: Impacts, Adaptation and Vulnerability. In M.L. Parry, O.F. Canziani, J.P. Palutikof, P.J. van der Linden \& C.E. Hanson, Eds., Contribution of Working Group II to the Fourth Assessment Report of the Intergovernmental Panel on Climate Change. Cambridge: Cambridge University Press.

IPCC (Intergovernmental Panel on Climate Change). 2012. Managing the risks of extreme events and disasters to advance climate change adaptation. A special report of Working Groups I and II of the Intergovernmental Panel on Climate Change. C.B. Field, V. Barros, T.F. Stocker, D. Qin, D.J. Dokken, K.L. Ebi, M.D. Mastrandrea, K.J. Mach, G-K. Plattner, S.K. Allen, M. Tignor \& P.M. Midgley, eds., Cambridge, UK, and New York, USA, Cambridge University Press.

IPCC. 2014. Working Group II contribution to the IPCC Fifth Assessment Report Climate Change 2014: Impacts, Adaptation, and Vulnerability.

ILO (International Labour Organisation). 2010. Employment diagnostic analysis on Malawi. Prepared for the Government of Malawi by Professor Dick Durevall and Dr. Richard Mussa, with assistance from the International Labour Organisation. Geneva, Switzerland.

Jain, S. 2007. "An empirical economic assessment of impacts of climate change on agriculture in Zambia", Policy Research Working Paper No. 4291, The World Bank Development Research Group, Washington D.C.

Jones, A. D., Shrinvas, A., \& Bezner-Kerr, R. (2014). Farm production diversity is associated with greater household dietary diversity in Malawi: Findings from nationally representative data. Food Policy, 46, 1-12. doi:10.1016/j.foodpol.2014.02.001

Kanyanga, J., Thomas, T. S., Hachigonta, S. and Sibanda, L.M. 2013. "Zambia" in Southern African Agriculture and Climate Change, eds. Hachigonta, S., Nelson, G.C., Thomas, T.S. and Sibanda, L.M. International Food Policy Research Institute, Washington, DC.

Karttunen, K. 2009. "Rural income generation and diversification: A case study in Eastern Zambia." PhD Dissertation, University of Helsinki Department of Economics and Management, Publication No 47, Agricultural Policy, Helsinki.

Kihara, J., MacCarthy, D.S., Bationo, A., Koala, S., Hickman, J., Koo, J., Vanya, C., Adiku, S., Beletse, Y., Masikate, P., Rao, K.P.C., Mutter, C.Z., Rosenzweig, C. and Jones, J. W. 2015. "Perspectives on climate effects on agriculture: The international efforts of AgMIP in SubSaharan Africa," in Handbook of Climate Change and Agroecosystems: The Agricultural Model Intercomparison and Improvement Project (AgMIP), Part 2. C. Rosenzweig, and D. Hillel, Eds., ICP Series on Climate Change Impacts, Adaptation, and Mitigation Vol. 3. Imperial College Press, 3-24, doi: 10.1142/9781783265640_0013

Lanjouw, P., Quizon, J. \& Sparrow, R. 2001. Non-agricultural earnings in peri-urban areas of Tanzania: evidence from household survey data. Food Policy 26(4): 385-403.

Lay, J., Mahmood, T.O. \& M'mukaria, G. M. 2008. Few opportunities, much desperation: The dichotomy of non-agricultural activities and inequality in Western Kenya. World Development 36(12): 2713-2732.

Lay, J., Nahrloch, U. \& Omar Mahmoud, T. 2009. Shocks, structural change, and the patterns of income diversification in Burkina Faso. African Development Review 21(1): 36-58. 
Lobell, D., Burke, M., Tebaldi, C., Mastrandrea, M., Falcon, W. and Naylor, R. 2008. "Prioritizing climate change adaptation needs for food security in 2030," Science, 319: 607-610. doi: $10.1126 /$ science. 1152339

Losch, B., Freguingresh, S. \& White, E. 2011. Rural transformation and late developing countries in a globalizing world: a comparative analysis of rural change. Final Report of the RuralStruc Program, Revised Version, Washington, DC, World Bank.

Lipper, L. \& Thornton, P. 2014. How Does Climate Change Alter Agricultural Strategies to Support Food Security? IFPRI Discussion Paper 01340.

Macours, K., Premand, P. \& Vakis, R. 2012. Transfers, diversification and household risk strategies: experimental evidence with lessons for climate change adaptation. Policy Research Working Paper 6053, Washington, DC, World Bank.

Martin, S. M. and Lorenzen, K. 2016. "Livelihood Diversification in Rural Laos." World Development (in press). Doi: 10.1016/j.worlddev.2016.01.018

Mason, N. M., Jayne, T.S. and Mofya-Mukuka, R. 2013. "Zambia's input subsidy programs," Agricultural Economics, 44: 613-628. doi: 10.1111/agec.12077

Moret, Whitney. 2014. "Vulnerability Assessment Methodologies: A Review of the Literature." Report commissioned by the USAID, ASPIRES.: http://www.fhi360.org/resource/ vulnerability-assessment-methodologies-review-literature

Mortimore, M.J. \& Adams, W.M. 2001. Farmer adaptation, change and crisis in the Sahel. Global Environmental Change 11(1): 49-57.

Murdoch, J. (1995). Income smoothing and consumption smoothing. The Journal of Economic Perspectives, 9(3), 103-114. doi:10.1257/jep.9.3.103

Nelson, G.C., van der Mensbrugghe, D. 2013. "Public Sector Agricultural Research Priorities for Sustainable Food Security: Perspectives from Plausible Scenarios." Background paper for the conference "Food Security Futures: Research Priorities for the 21st Century," April 11-12 2013, Dublin.

Newsham, A. \& Thomas, D. 2009. Agricultural adaptation, local knowledge and livelihoods diversification in north-central Namibia. Tyndall Working Paper 140.

Pingali, P. \& Rosegrant, M. 1995. Agricultural commercialization and diversification: processes and polices. Food Policy 20(3): 171-185.

Pope, R. D., \& Prescott, R. (1980). Diversification in relation to farm size and other socioeconomic characteristics. American Journal of Agricultural Economics, 62, 554-559. doi:10.2307/1240214

Reardon, T. 1997. Using Evidence of Household Income Diversification to Inform Study of the Rural Nonfarm Labour Market in Africa. World Development 25(5): 735-747. doi:10.1016/ S0305-750X(96)00137-4

Reardon, T., Stamoulis, K., Balisacan, A., Cruz, M.E., Berdegue, J. \& Banks, B. 1998. Rural Nonfarm Income in Developing Countries. Special Chapter in The State of Food and Agriculture 1998. Rome, FAO.

Reardon, T., Taylor, J. E., Stamoulis, K., Lanjouw, P., \& Balisacan, A. 2000. "Effects of non-farm employment on rural income inequality in developing countries: An investment perspective." Journal of Agricultural Economics, 51, pp. 266-288.

Reardon, T., Berdegué, J., Barrett, C.B. \& Stamoulis, K. 2007. Household Income Diversification into Rural Nonfarm Activities. In S. Haggblade, P. Hazell \& T. Reardon, eds. Transforming the Rural Nonfarm Economy. Baltimore, MA, USA, Johns Hopkins University Press.

Richard E. and Pope, Rulon D. 2001. The Agricultural Producer: Theory and statistical Measurement. Chapter 12 in Handbook of Agricultural Economics, Volume 1, Edited by B. Gardner and G. Rausser, Elsevier Science B.V.

Seo, S., Mendelsohn, R., Dinar, A., Hassan, R. \& Kurukulasuriya, P. 2009. A Ricardian analysis of the distribution of climate change impacts on agriculture across agro-ecological zones in Africa. Environmental and Resource Economics 43(3): 313-332.

Singh, I., Squire, L. \& Strauss, J. (eds.) 1986. Agricultural Housheold Models. Baltimore: The Johns Hopkins University Press. 
Smale, M., ed. 2006. Valuing crop diversity: on-farm genetic resources and economic change. Ch. 1, Wallingford, UK, CABI Publishing.

Smit, B., \& Wandel, J. (2006). Adaptation, adaptive capacity and vulnerability. Global Environmental Change, 16(3), 282-292. doi:10.1016/j.gloenvcha.2006.03.008

Toulmin, C., Leonard, R., Brock, K., Coulibaly, N., Carswell, G. \& Dea, D. 2000. Diversification of livelihoods: evidence from Mali and Ethiopia. Research Report 47, Brighton, UK, Institute of Development Studies.

Thurlow, J., Zhu, T. and Diao, X. 2012. "Current Climate Variability and Future Climate Change: Estimated Growth and Poverty Impacts for Zambia." Review of Development Economics 16(3), 394-411. doi:10.1111/j.1467-9361.2012.00670.x

Van Dusen, M.E. \& Taylor, J.E. 2005. Missing markets and crop diversity: evidence from Mexico. Environment and Development Economics 10(04): 513-531.

Wang, J., Mendelsohn, R., Dinar, A. \& Huang, J. 2009. How do China's farmers adapt to climate change? Paper presented at the International Association of Agricultural Economics Conference, Beijing.

Wheeler, David. 2011. "Quantifying Vulnerability to Climate Change: Implications for Adaptation Assistance.” CGD Working Paper 240. Washington, D.C.: Center for Global Development. http://www.cgdev.org/content/publications/detail/1424759

World Bank 2012. Mainstreaming adaptation to climate change and natural resource management. Washington, DC.

World Bank 2013. "Poverty headcount ratio at $\$ 1.25$ a day (PPP)" and "Agriculture, value added (\% of GDP)" in World Development Indicators, Zambia. Accessed on October 152013 at: http://data.worldbank.org/country/zambia

Open Access This chapter is distributed under the terms of the Creative Commons AttributionNonCommercial-ShareAlike 3.0 IGO license (https://creativecommons.org/licenses/by-nc-sa/3.0/ $\mathrm{igo//),} \mathrm{which} \mathrm{permits} \mathrm{any} \mathrm{noncommercial} \mathrm{use,} \mathrm{duplication,} \mathrm{adaptation,} \mathrm{distribution,} \mathrm{and} \mathrm{reproduction}$ in any medium or format, as long as you give appropriate credit to the Food and Agriculture Organization of the United Nations (FAO), provide a link to the Creative Commons license and indicate if changes were made. If you remix, transform, or build upon this book or a part thereof, you must distribute your contributions under the same license as the original. Any dispute related to the use of the works of the FAO that cannot be settled amicably shall be submitted to arbitration pursuant to the UNCITRAL rules. The use of the FAO's name for any purpose other than for attribution, and the use of the FAO's logo, shall be subject to a separate written license agreement between the FAO and the user and is not authorized as part of this CC-IGO license. Note that the link provided above includes additional terms and conditions of the license.

The images or other third party material in this chapter are included in the chapter's Creative Commons license, unless indicated otherwise in a credit line to the material. If material is not included in the chapter's Creative Commons license and your intended use is not permitted by statutory regulation or exceeds the permitted use, you will need to obtain permission directly from the copyright holder.

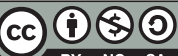

